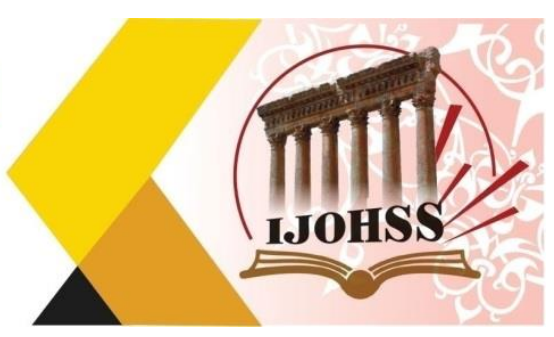

\title{
الأدوار المستحدثة للمدعي العام في العراق
}

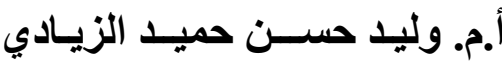 \\ أستاذ القانون العام المساعد المبل \\ كلية القانون - جامعة القادسية \\ العراق جون إمعاق \\ Waleed.Hassan@qu.edu.iq
}

الملخص

بات من الثابت لاى قليلي الثقافة القانونية ومايلحق بهم من المتجردين منها، يرون بأن ليس للمدعي العام في

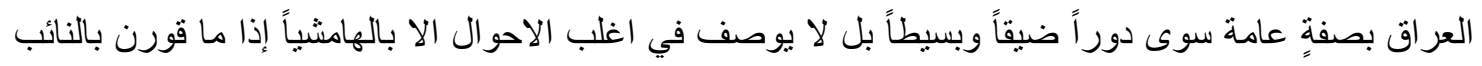
العام في مصر مثنلا، الا ان الحال يختلف كلياً بالنسبة لمن يمتلك قدر اً كبير اً من الوعي القانوني سيما من يعمل في

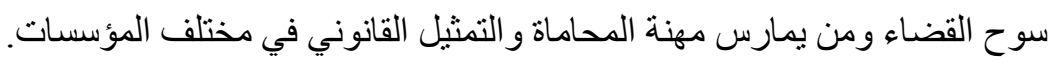
إذ ان الناظر لأول و هلة يرى بأن اختصاصات المدعي العام أضحت كثيرةٌ ومتنو عة ومتز ايدة والتي لايمكن

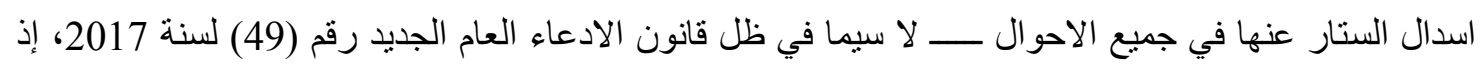
أنه فضلاً عن امتلاكه للاختصاصات التي تبدو وكانهها تقليدية كدوره في مجال الدعوى الجزائية و الدعاوى المدنية ومر اقبة المشروعية واحتر ام تطبيق القانون، أصبح يمنلك اختصاصات اخرى على قدرٍ كبير من الاهمية، و التي لايمكن وصفها الا بالمستحدثة، كدوره في الطعن بعدم دستورية القو انين والانظمة، وكذللك حضوره امام محاكم القضاء الإداري، والأكثر من ذلك اصبح له دوراً مزدوجاً تجلى واضحاً في مجال التحقيق وتمثيل الحق العام في قضايا الفساد المالي والإداري، يُذكر ان ما أستحدث من اختصاصات ساهم وبشكلٍ كبير في تقوية وتدعيم سلطة

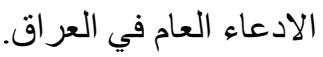

الكلمات المفتاحية: المدعي العام، العر اق. 


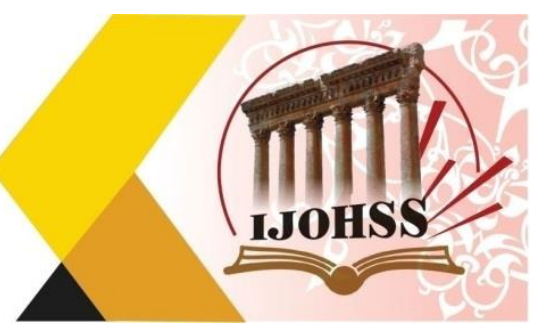

\title{
The New Roles of the General Attorney in Iraq
}

\author{
Assist. Prof. Waleed Hassan Hameed Al-Zayady \\ Assistant Professor of Public Law \\ College of Law - University of Al-Qadisiyah \\ Iraq \\ Waleed.Hassan@qu.edu.iq
}

\begin{abstract}
Has become fixed among those who have little legal culture and those who follow them. They believe that the attorney general in Iraq has only a narrow and simple role, and is not described in most cases except by marginality, as compared to the Attorney General in Egypt, for example. There have been many legal beliefs in various institutions.

As the viewer at first glance believes that the powers of the Prosecutor General have become many and varied and increasing, which can not be revealed in all cases, especially under the new Public Prosecution Law No. (49) for the year 2017, as well as having the competencies that appear to be traditional as his role in The scope of criminal proceedings, civil suits, monitoring of legality and respect for the application of the law, has acquired other powers of great importance, which can only be described as modern, such as its role in challenging the unconstitutionality of laws and regulations, as well as its presence before administrative courts, Clear in the field of investigation and representation of the public right in cases of financial and administrative corruption, it is noteworthy that the development of competencies contributed significantly to strengthen and strengthen the authority of the prosecution in Iraq.
\end{abstract}

Keywords: Public Prosecutor, Iraq. 


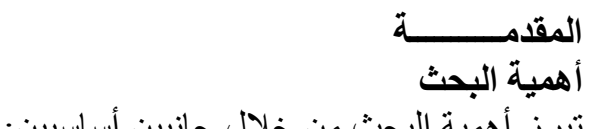

تبرز أهمية البحث من خلال جانبين أساسيين:

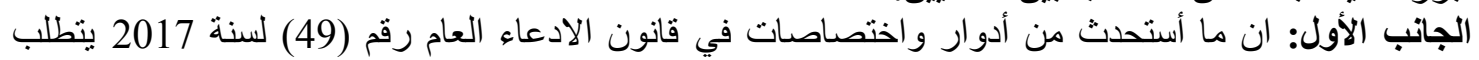

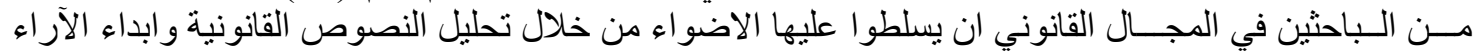

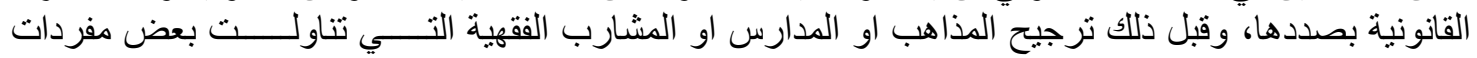

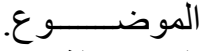

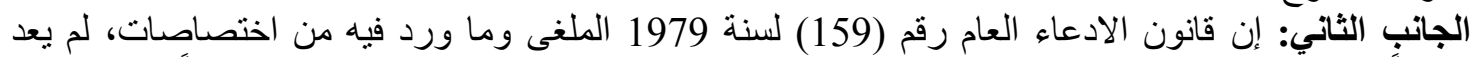

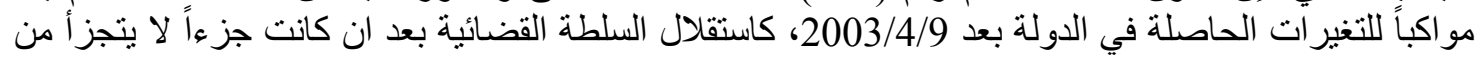

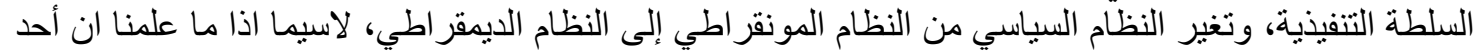

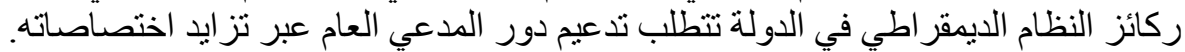
هدف البحث

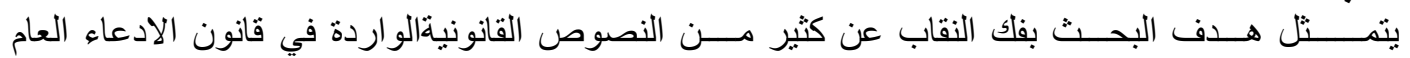

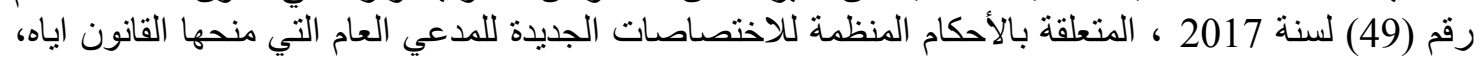

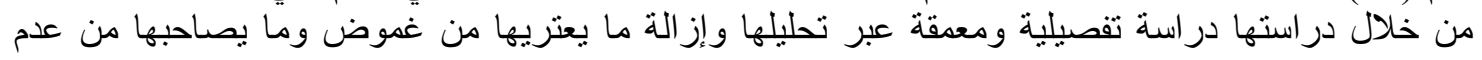

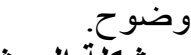

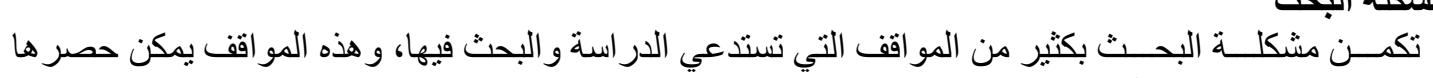
بثلاث نقاط اساسية وكما يلي: المبان

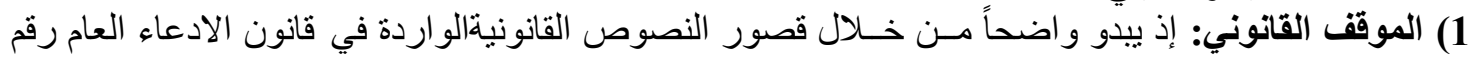

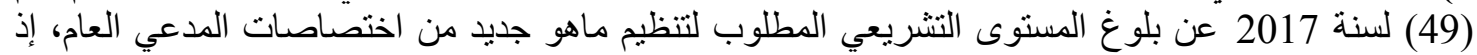

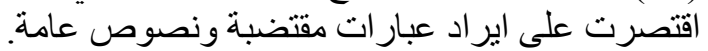

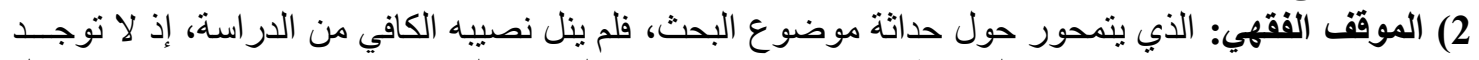

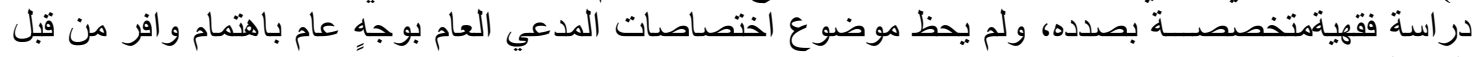
الفقه القانوني. 3) الموقف القضائي: الذي يتجسد بخلو سوح القضاء من القرار ات القضائية عن موضوع البحث. سنقتصر في بحثنا هذا على تبيان الأدوار المستحدثة للمدعي العام في إطار قانون الادعاء العام العر اقي رقم

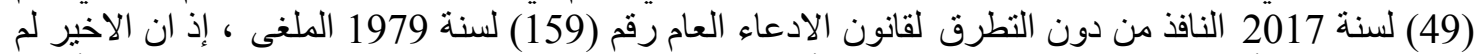

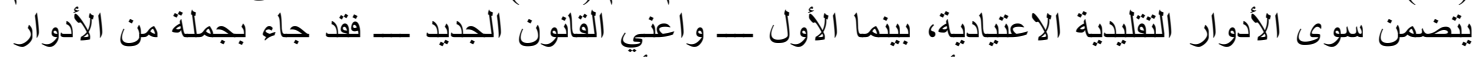

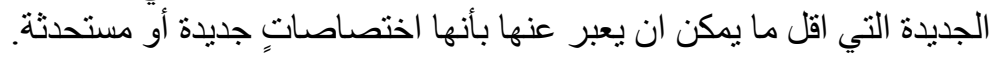

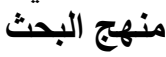

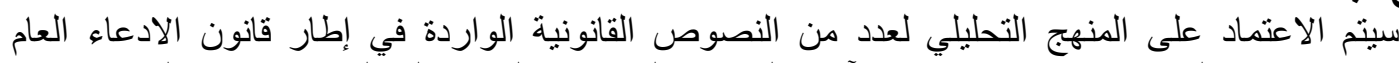

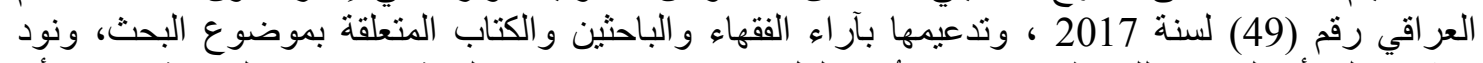

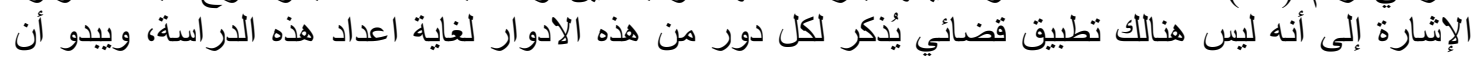

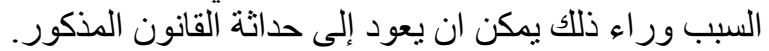

ارتأينا في دراستنا لموضوع الأدوار المستحدثة للمدعي العام في العراق، تقسيمها إلى ثلاثة مباحث تسبقها هيكلية البحث

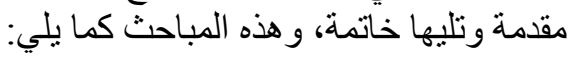




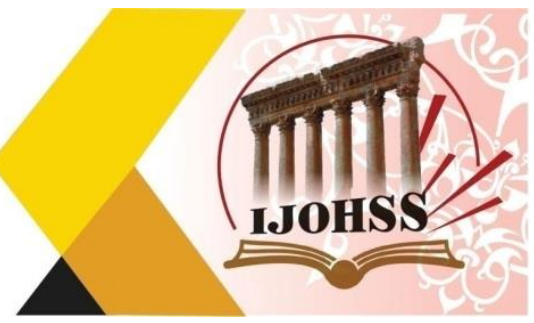

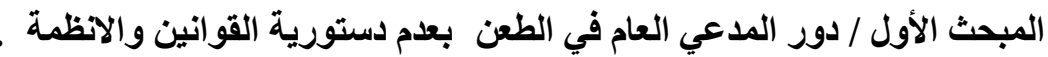

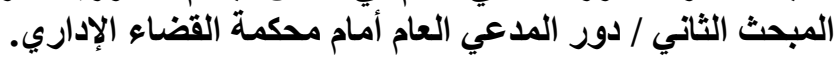

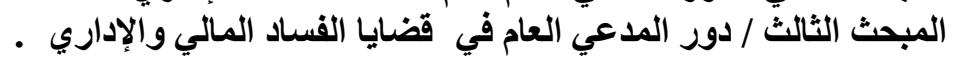

\section{المبحث الأول

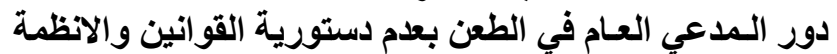

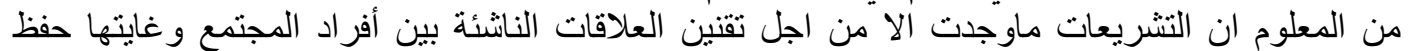

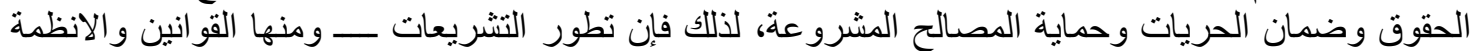

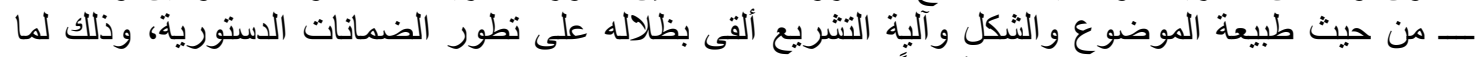

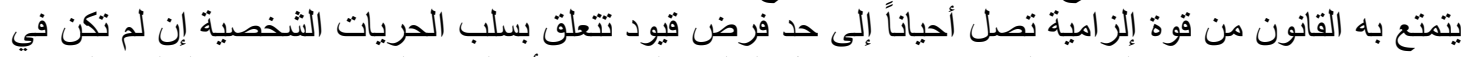

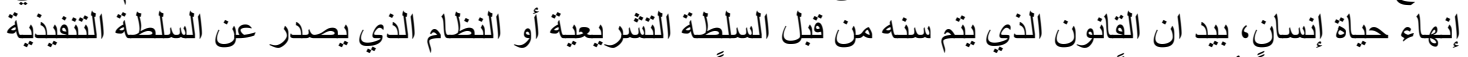

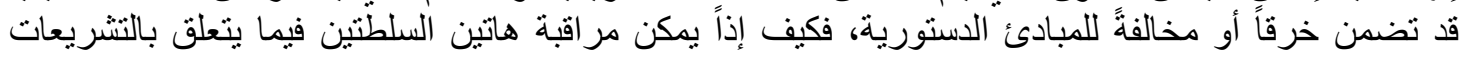

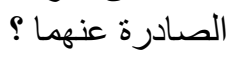

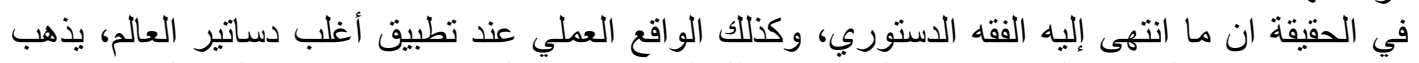

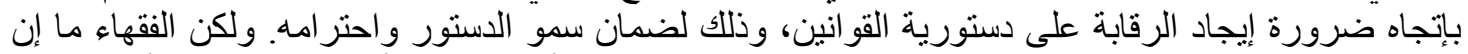

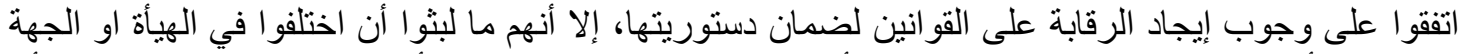

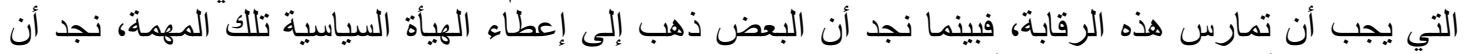

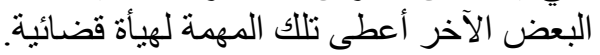

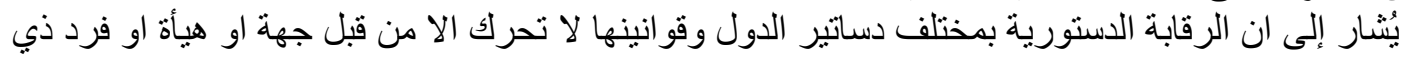

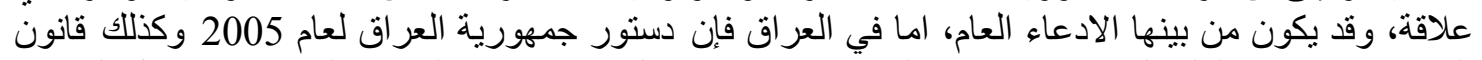

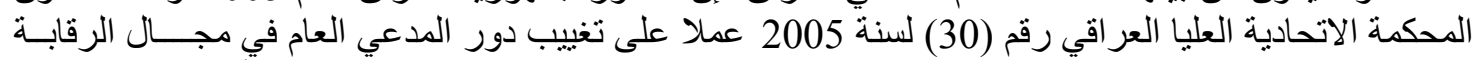

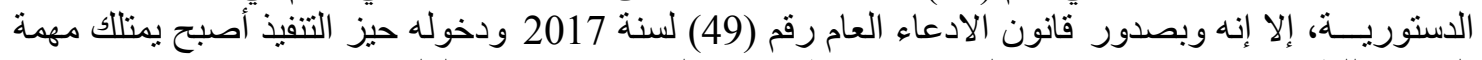

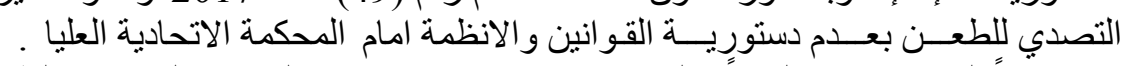

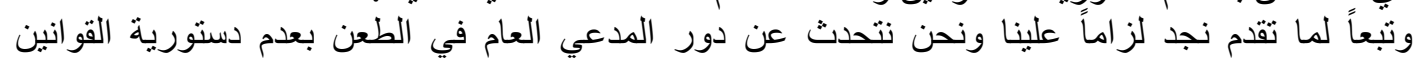

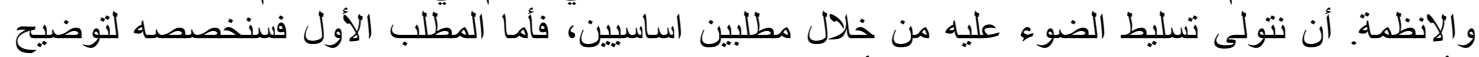

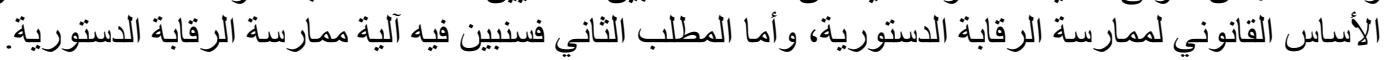
المطلب الأول المباني

الأساس القانوني لممارسة الرقابة الأبة الاستورية

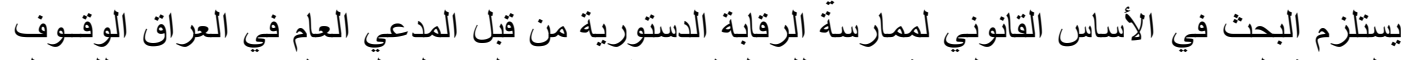

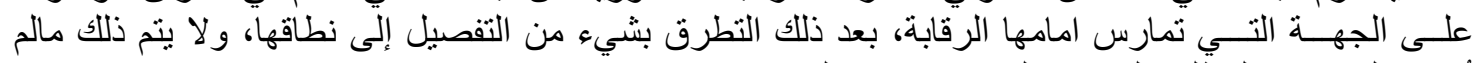
يُصار إلى تقسيم المطلب المذكور إلى فرعين مستقلين.

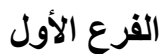

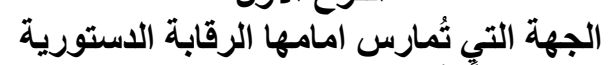

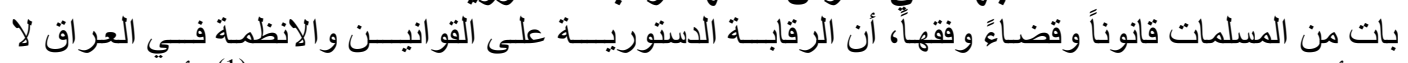

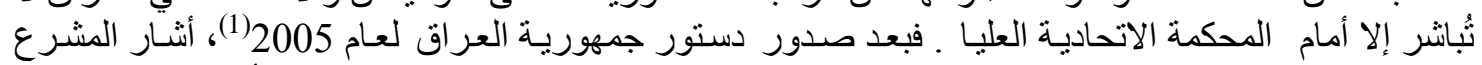

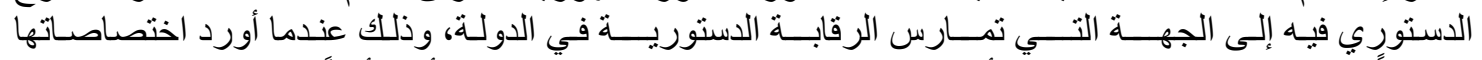

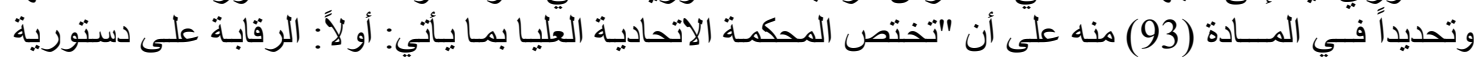

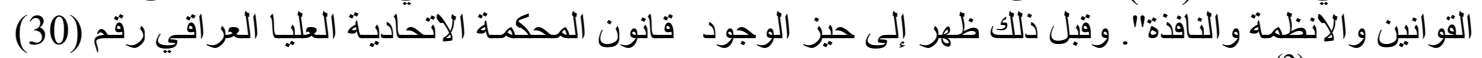

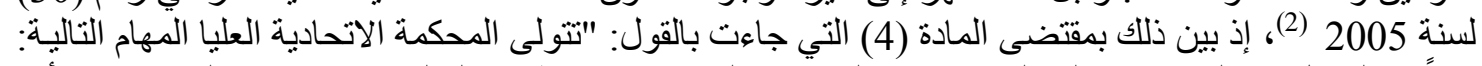

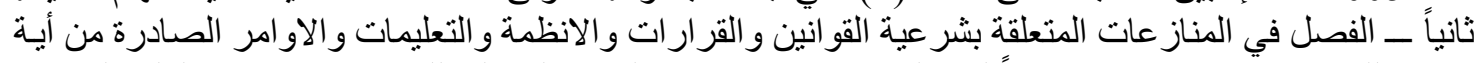

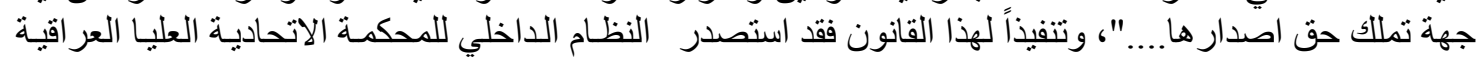




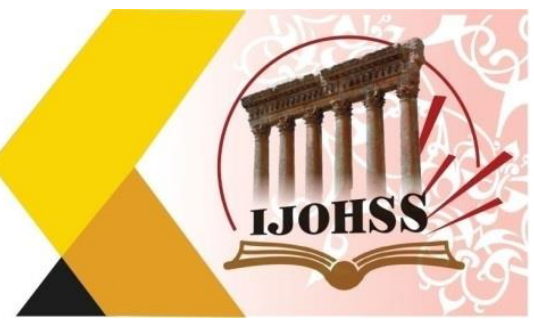

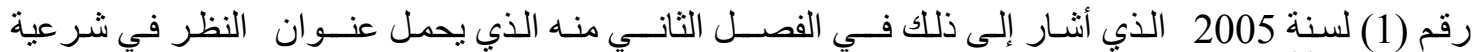
التشريعات (1) (1)

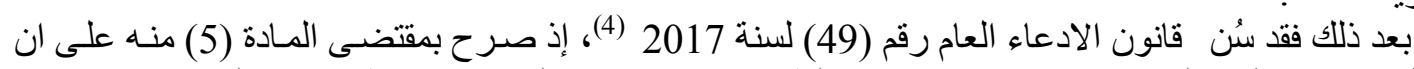

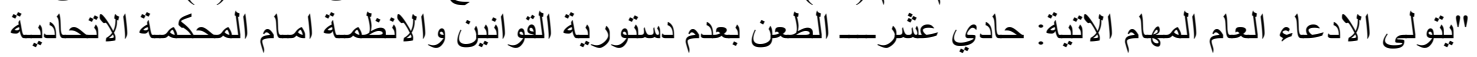
العليا".

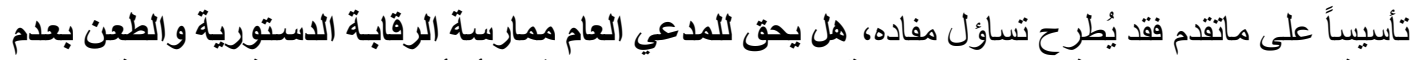

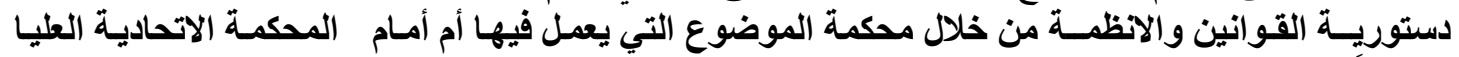

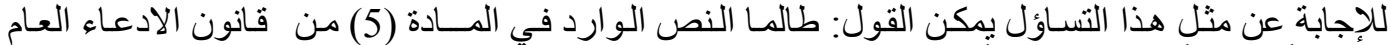

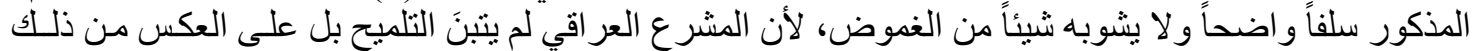

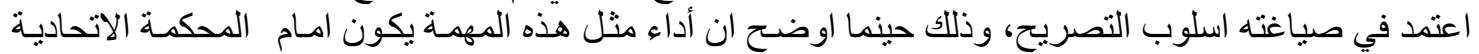

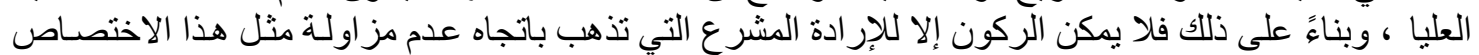

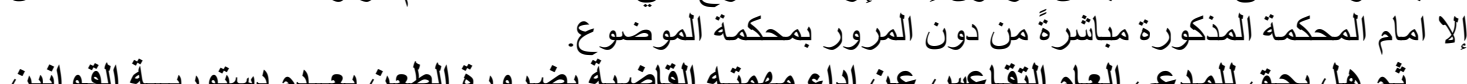

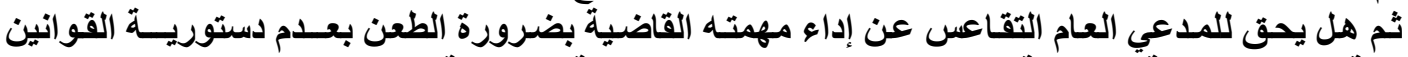

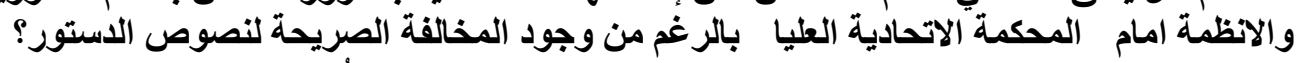

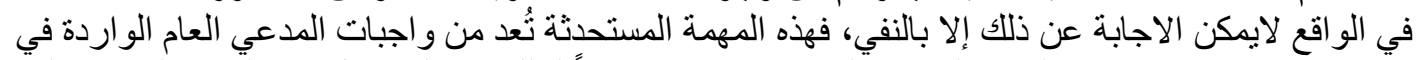

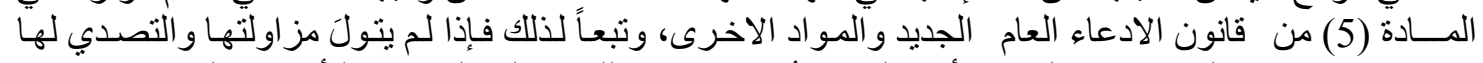

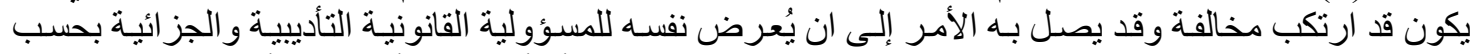

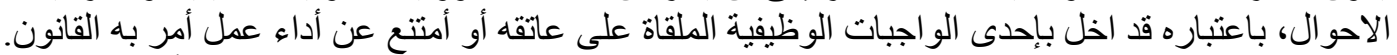

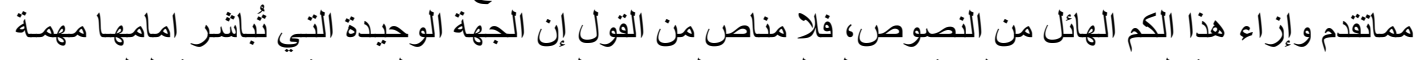

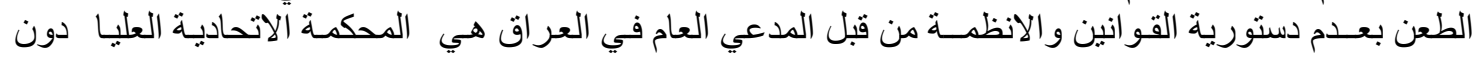

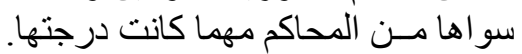

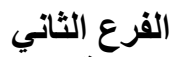 \\ نطاق الرقابة الاستثورية}

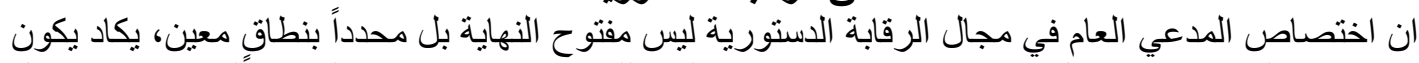

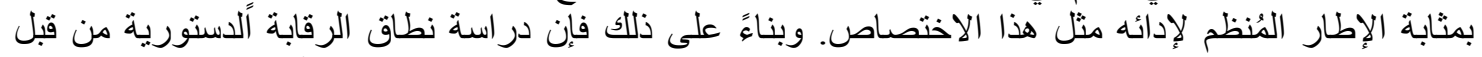

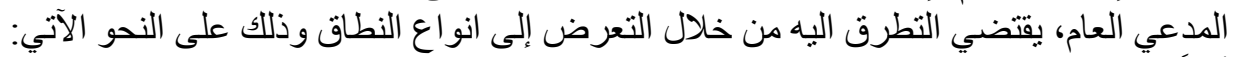

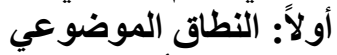

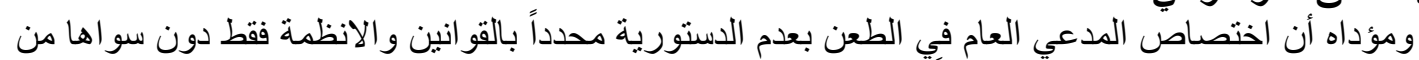

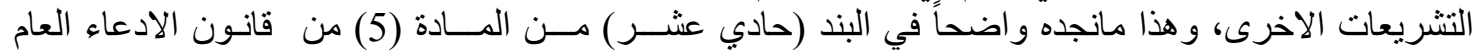

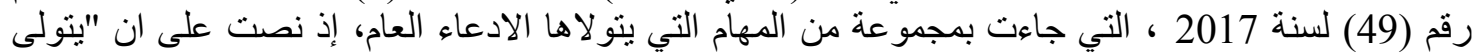

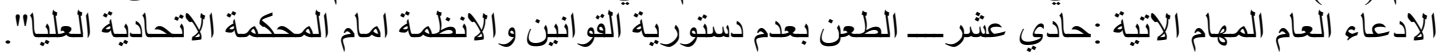

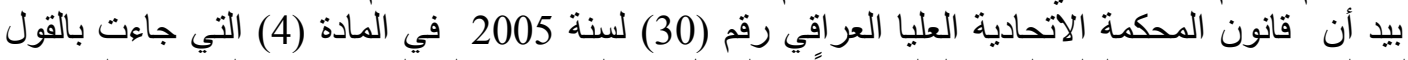

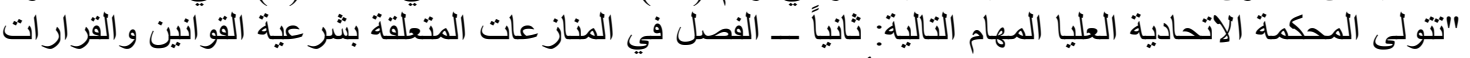

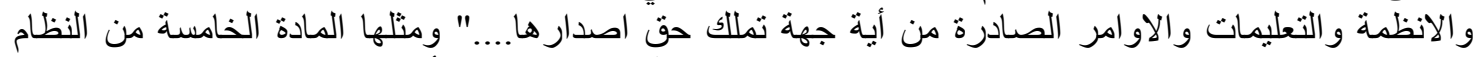

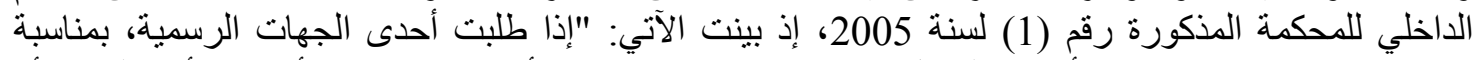

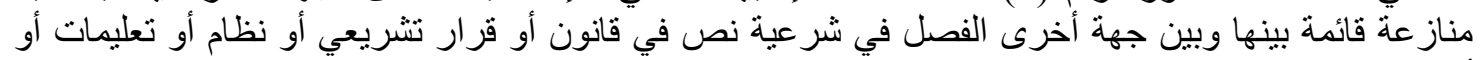

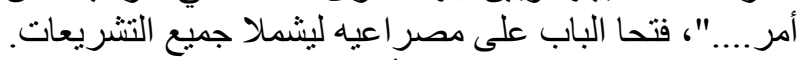

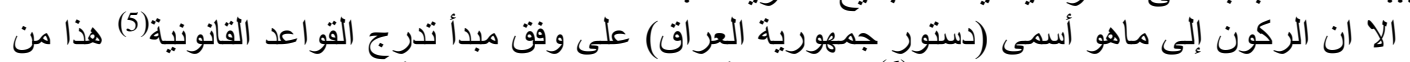

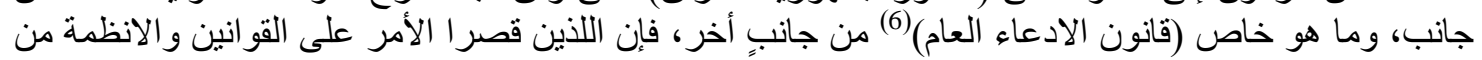

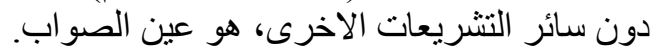




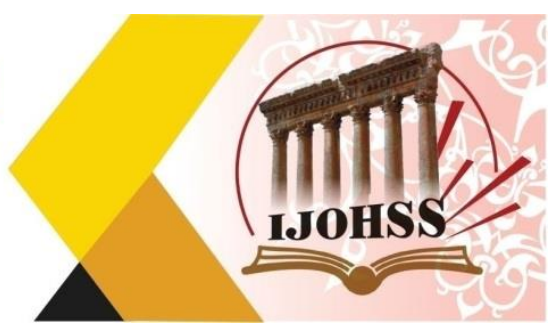

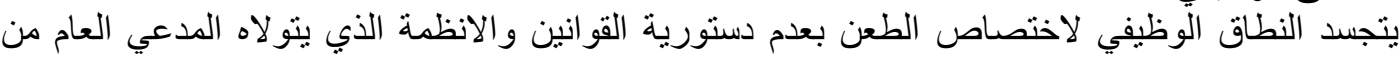

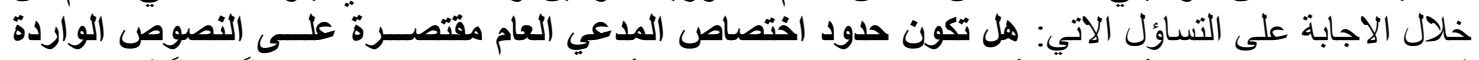

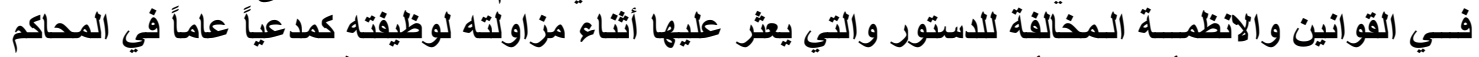

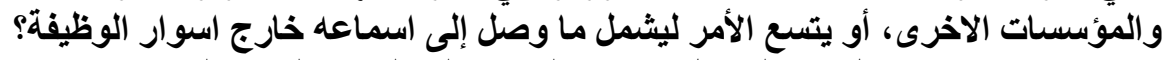

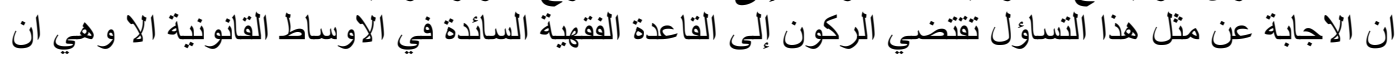

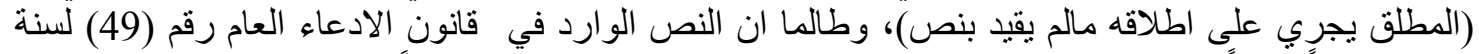

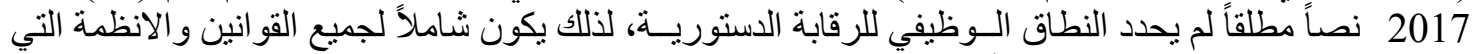

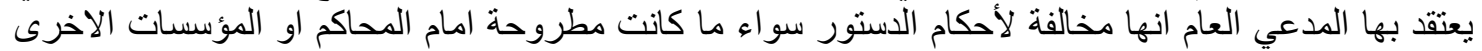
التي يعمل بها المدعي العام ام التي لم تصل إلى حلى المئل المناز عة ومن ثم لم تعرض على على المحاكم. ثُالثا: النطاق الزماني

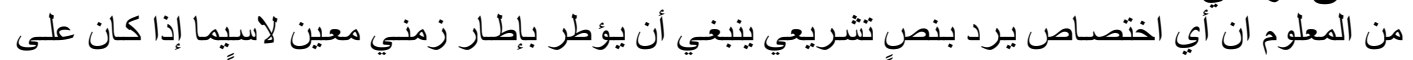

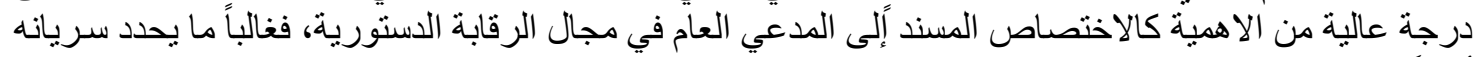

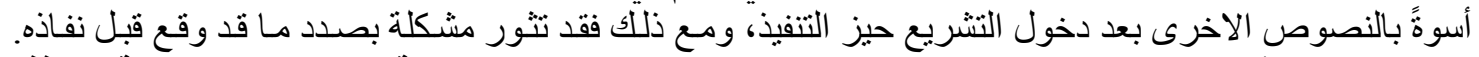

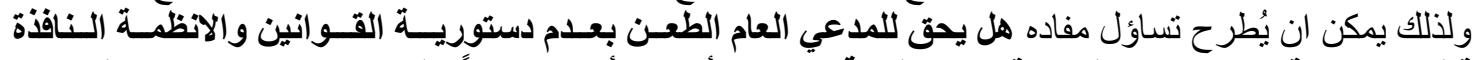

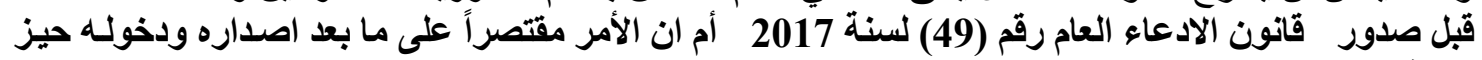
النفاذ؟

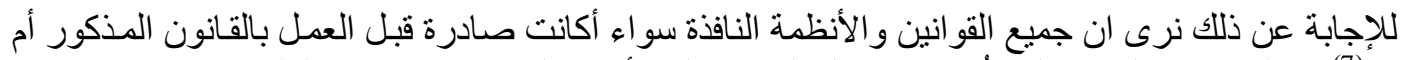

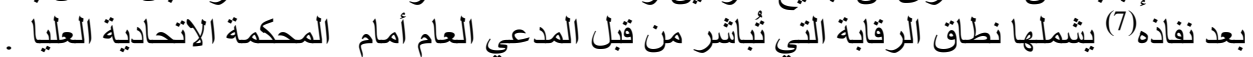
رابعاً: النطاق المكاني

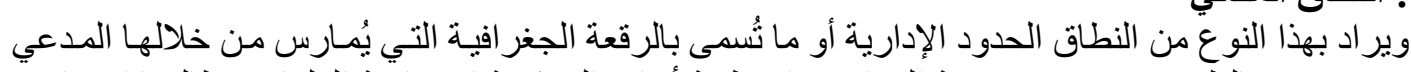

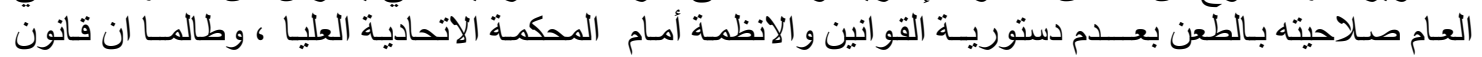

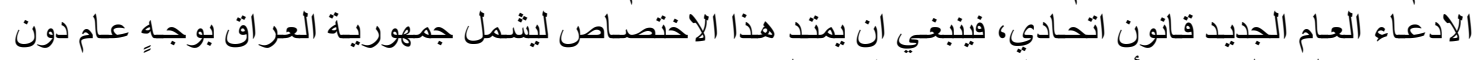

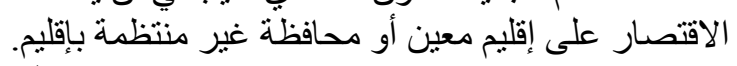

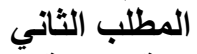

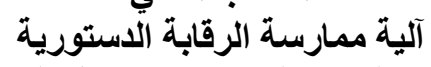

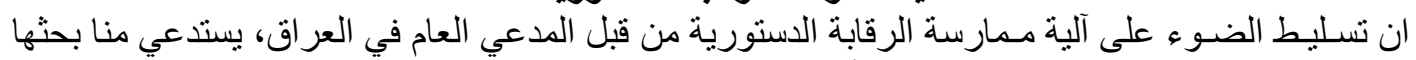

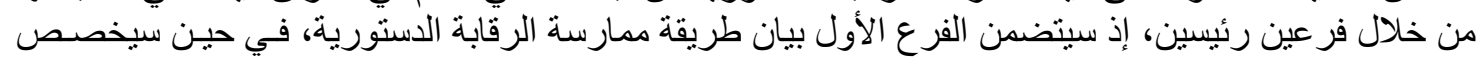
الفرع الثاني لدر اسة الاجر اءات الدينات المعدمة في مجال الرقابة الدستورية.

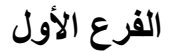

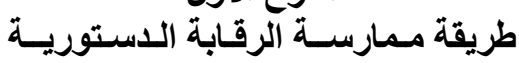

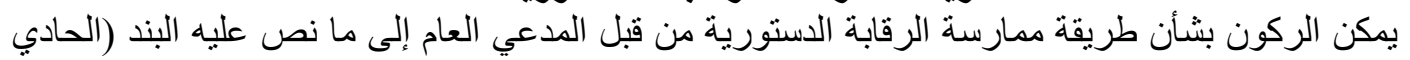

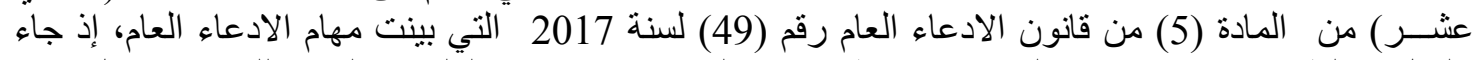

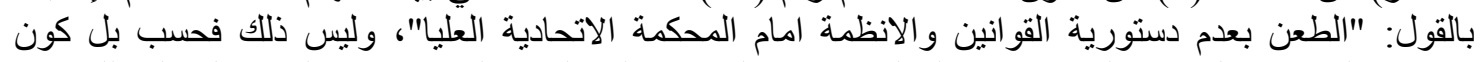

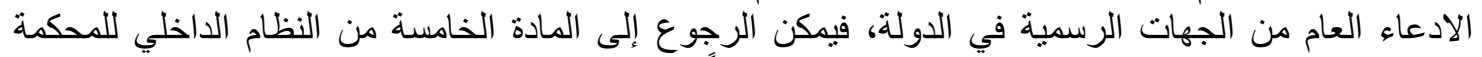

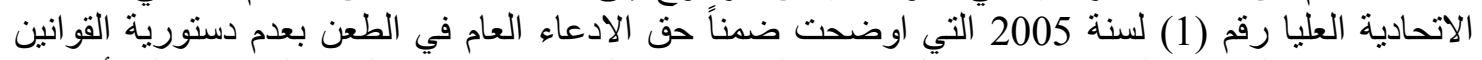

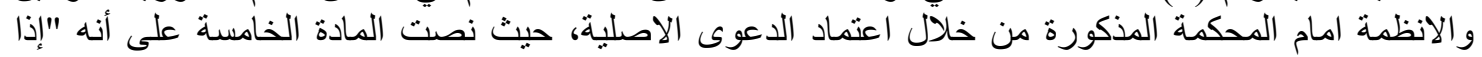

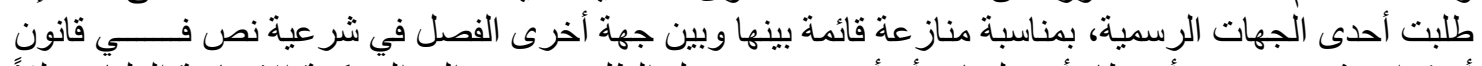

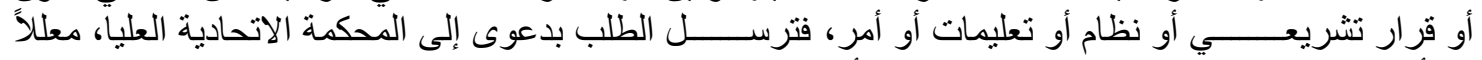

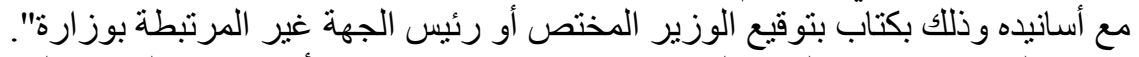

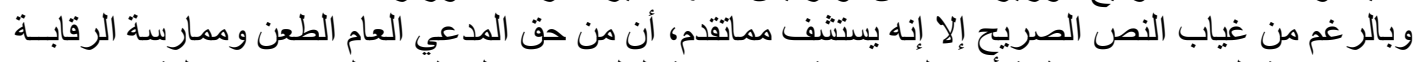

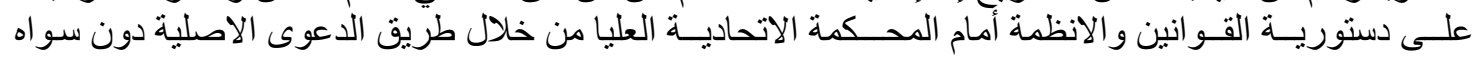

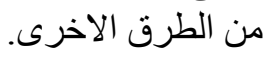




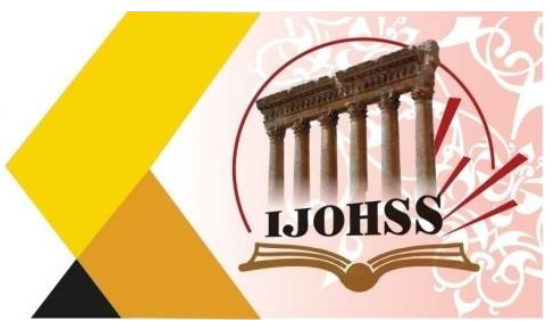

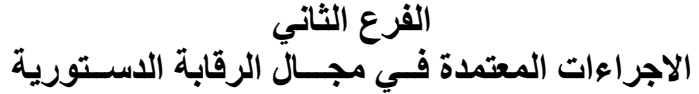

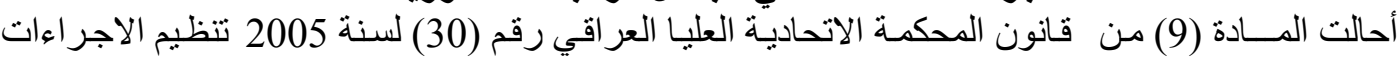

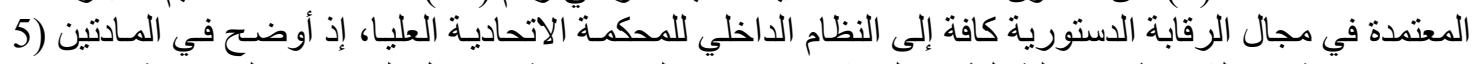

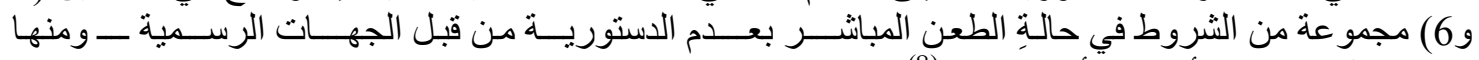

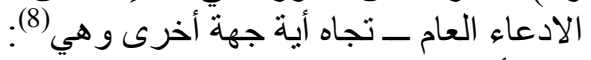

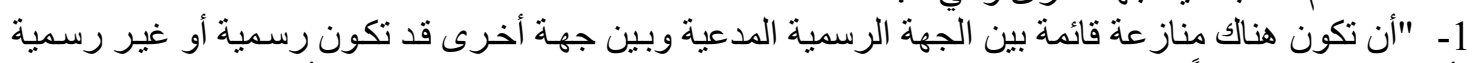

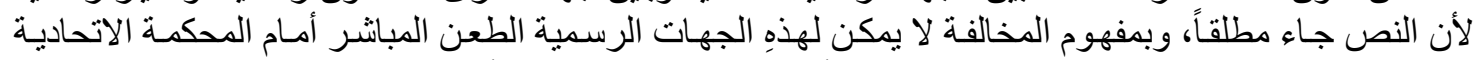

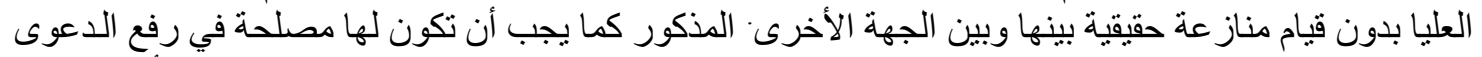

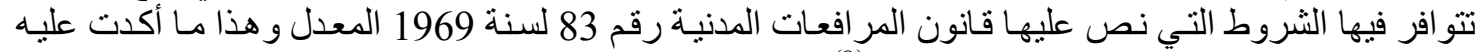

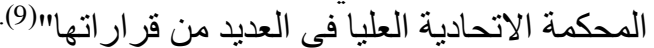

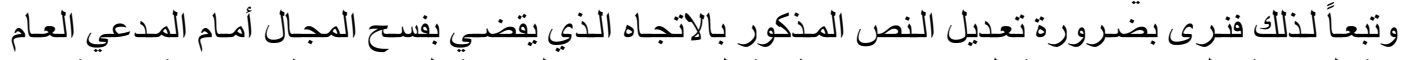

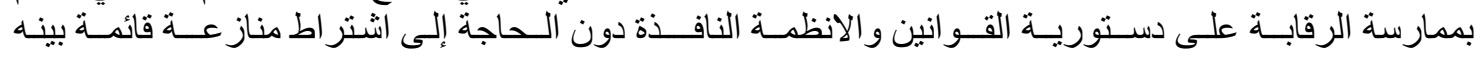

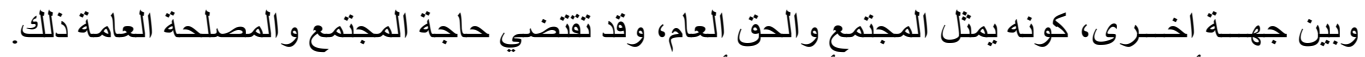

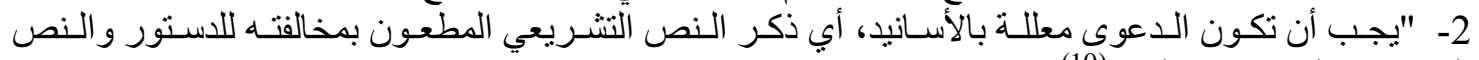

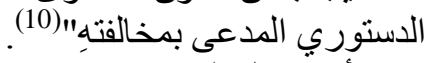

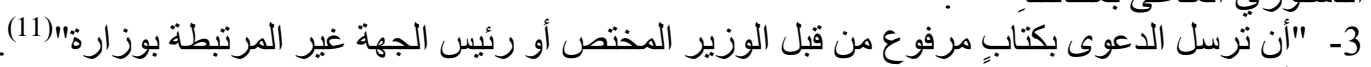

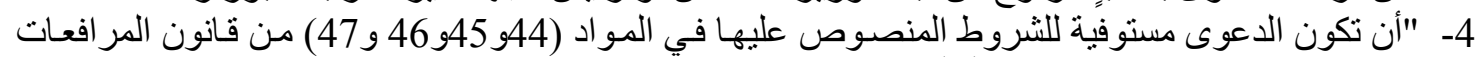

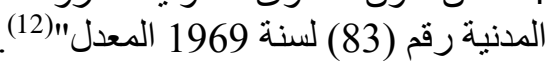

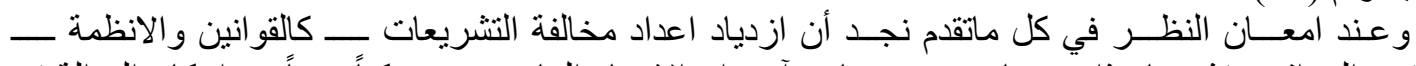

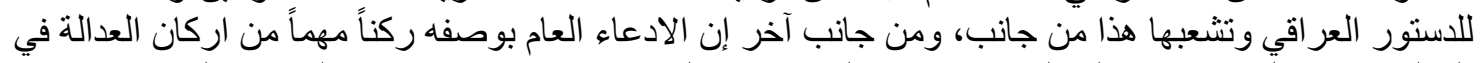

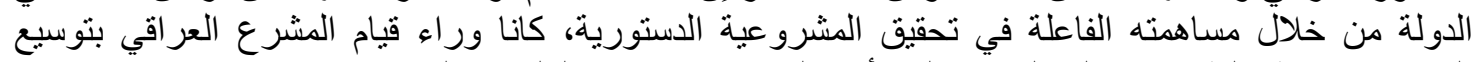
المشاركة واناطة الطعن فيها إلى المدعي العام أمام المحكمة الاتحادية العئية العليا في العراق.

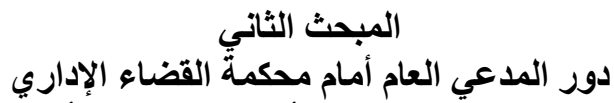

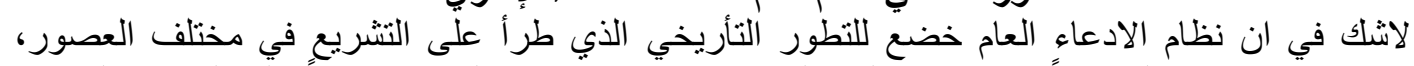

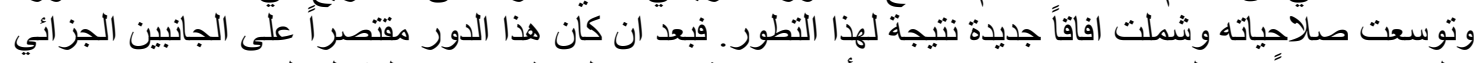

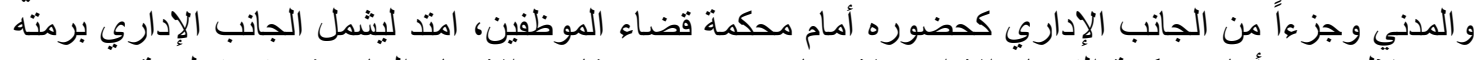

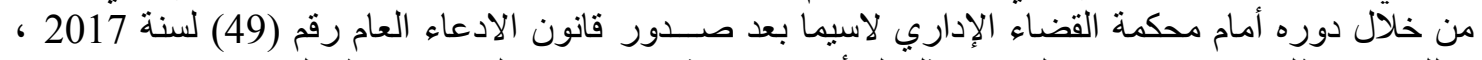

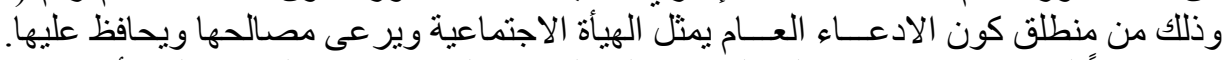

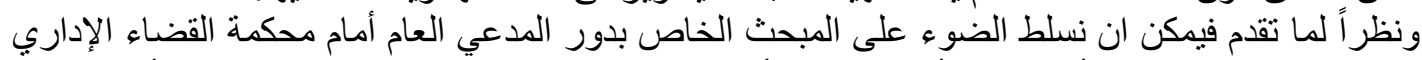

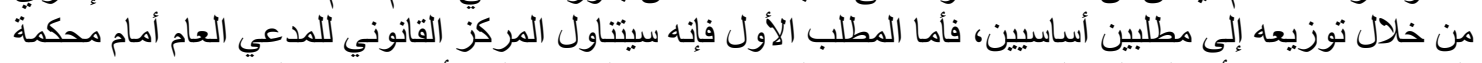

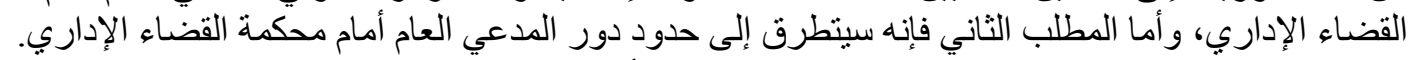

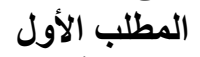

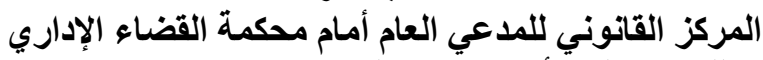

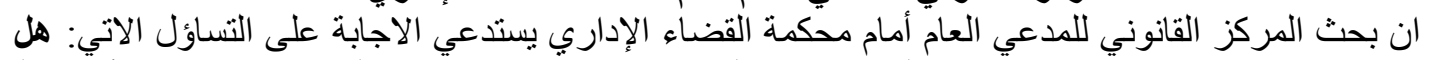

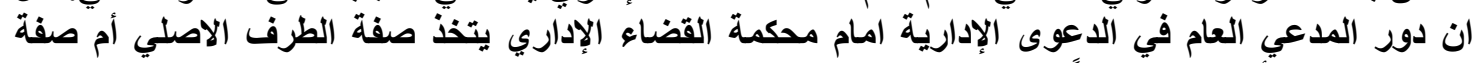

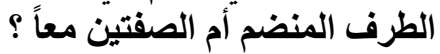

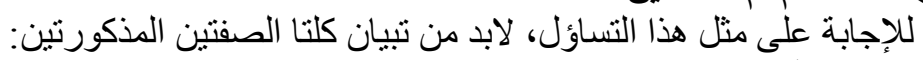

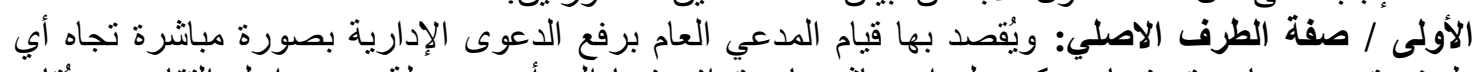

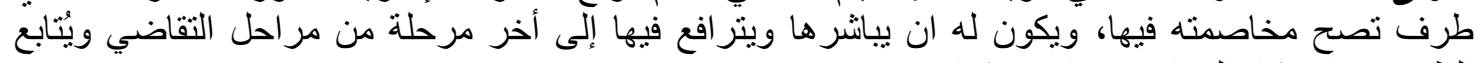
الطعن في الاحكام الصادرة فيها وتنفيذها. 


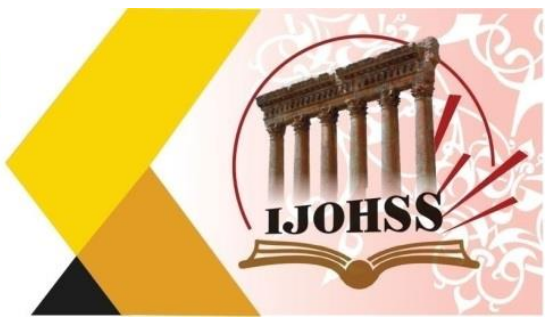

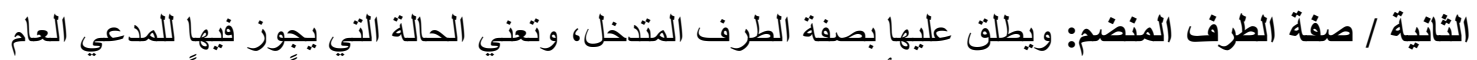

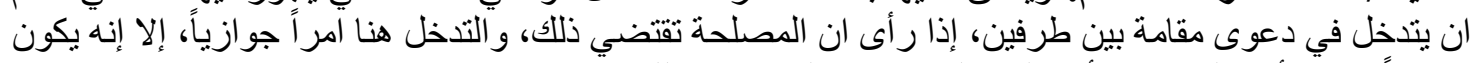

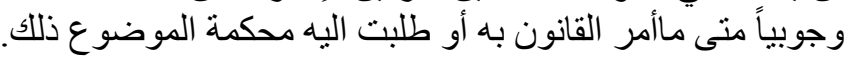

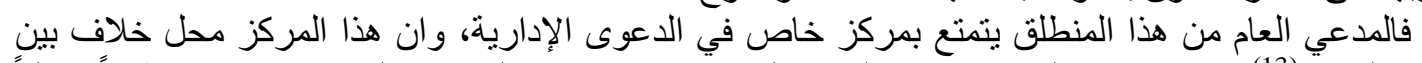

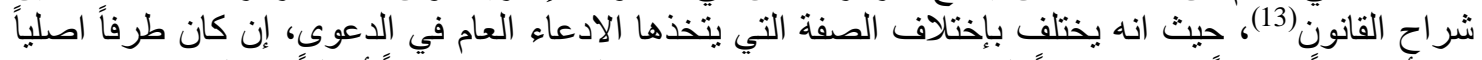

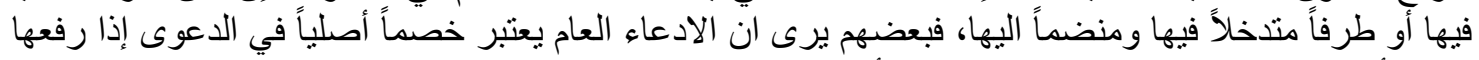

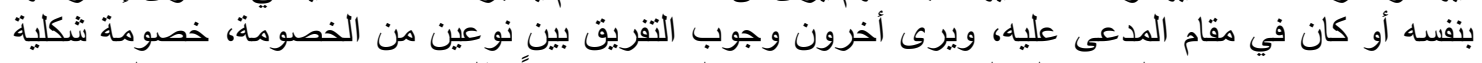

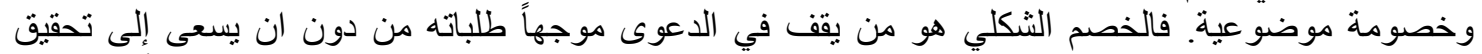

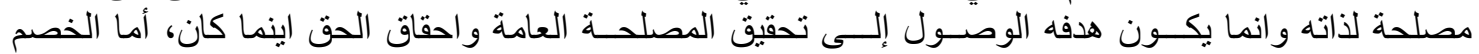

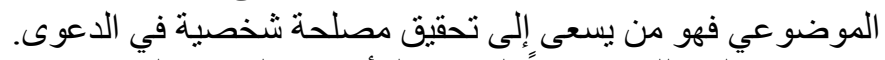

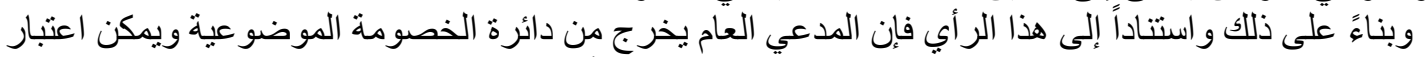

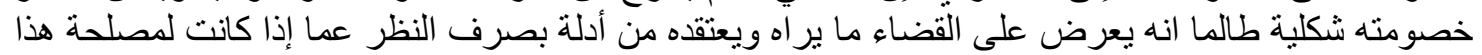
الطرف او ذاك. - الك.

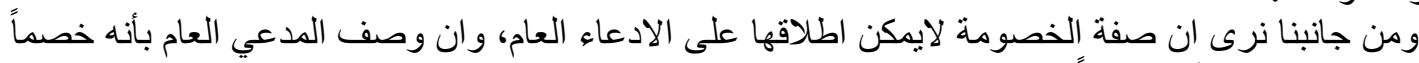

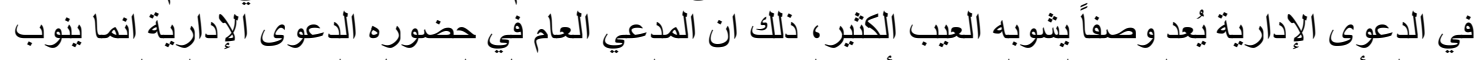

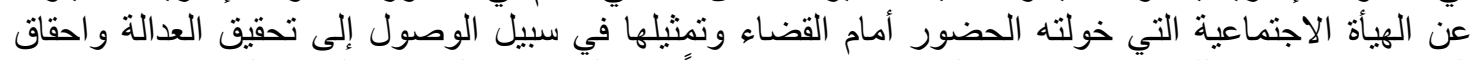

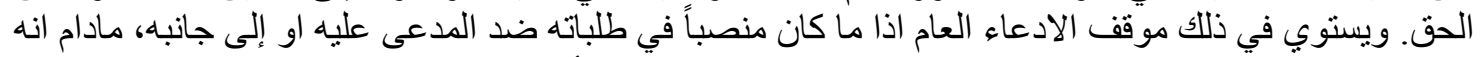

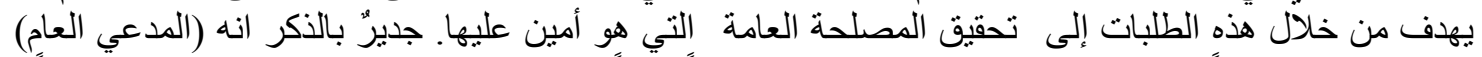

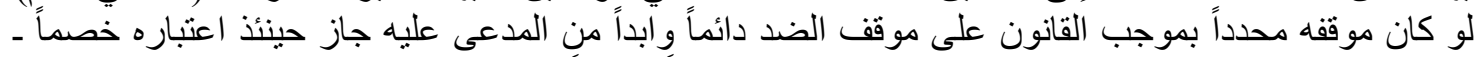

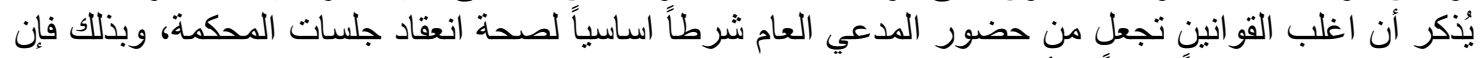
المدعي العام يعد جزء ألاً منمماً لهيأة المحكمة.

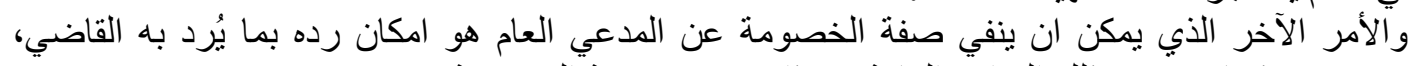

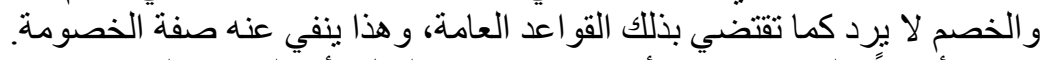

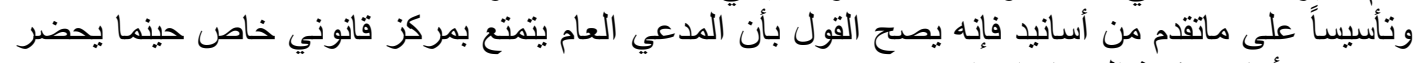
ويمارس دوره أمام محكمة القضاء الإداري.

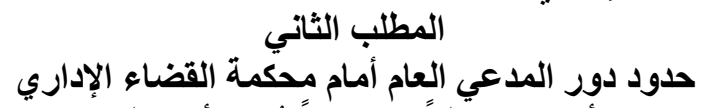

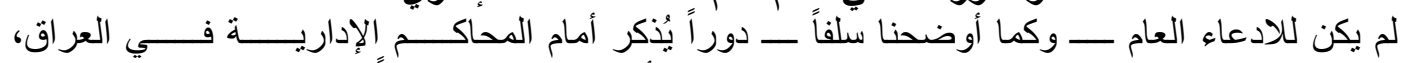

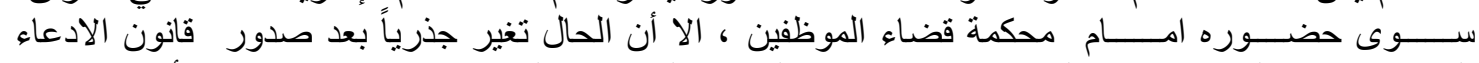

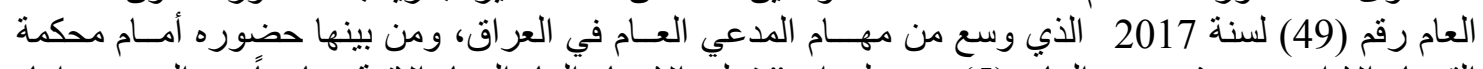

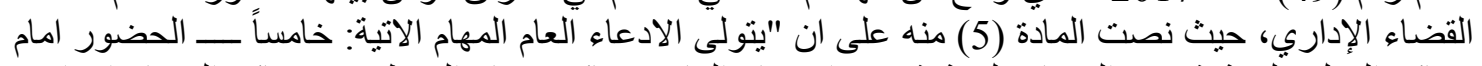

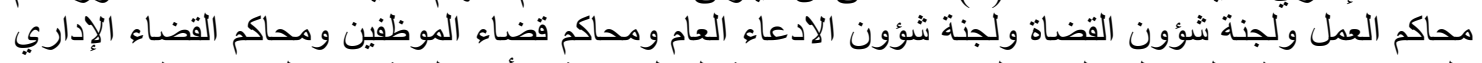

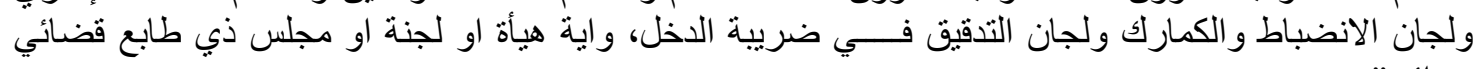

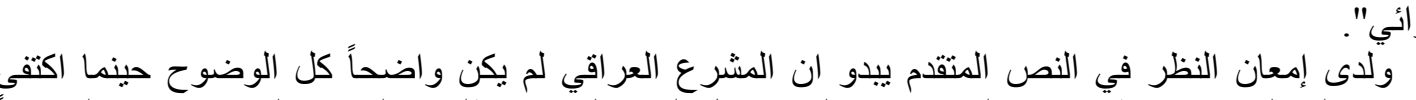

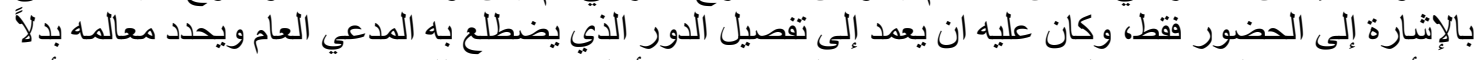

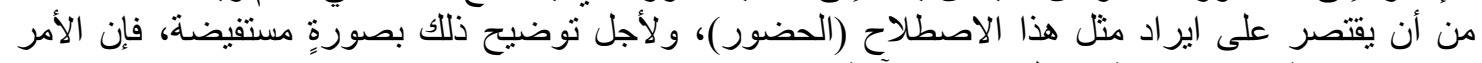
يقتضي الاجابة عن مجمو علة من التساؤ لاته الات الآتية:

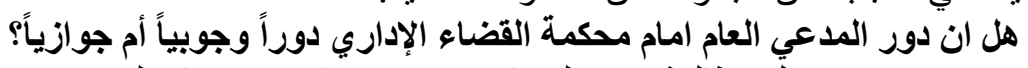

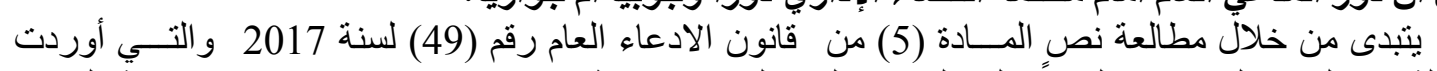

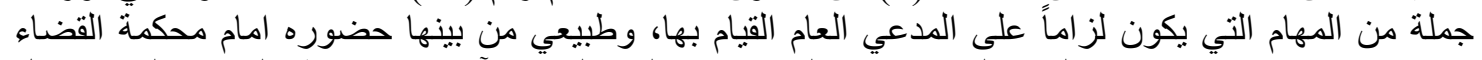

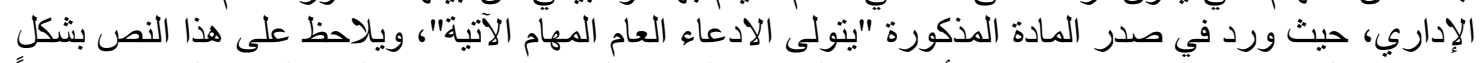

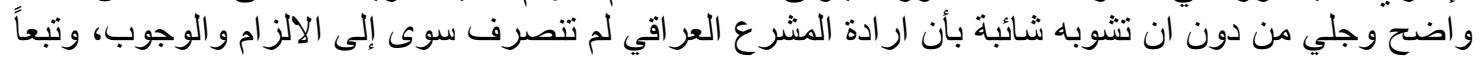




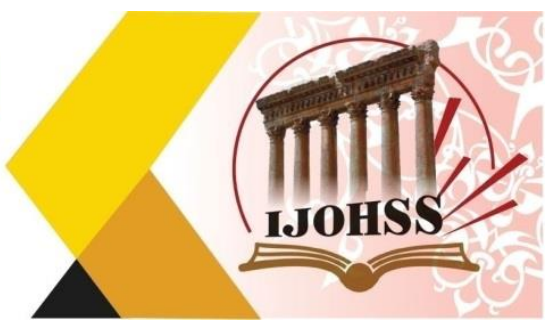

لذللك فلامجال للقول بجواز قبام المدعي العام بأداء دوره أمام محكمة القضاء الإداري بل على العكس من ذلك

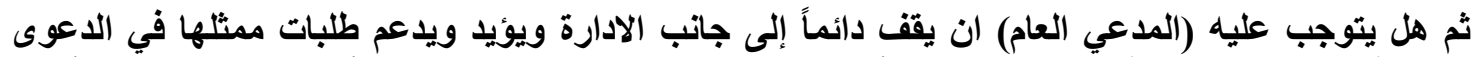

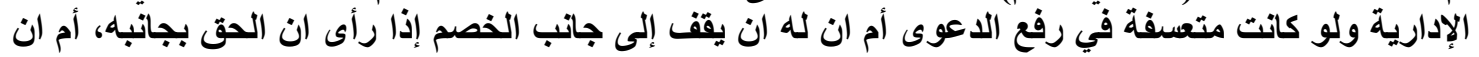

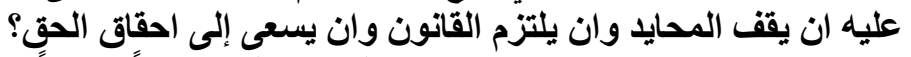

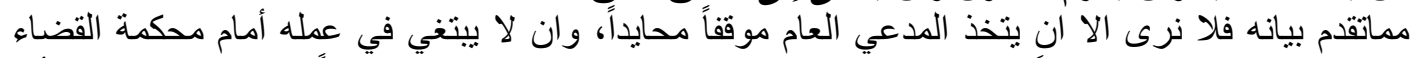

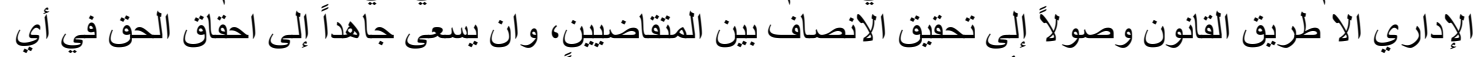

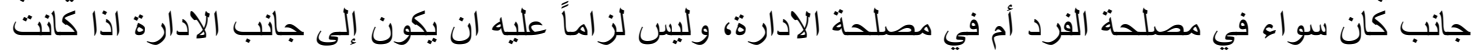
متعسفة في دعو اها أو غير محقة في طلباتها.

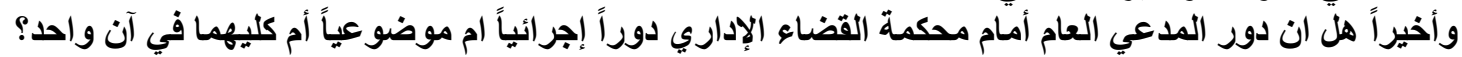

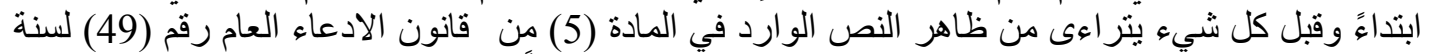

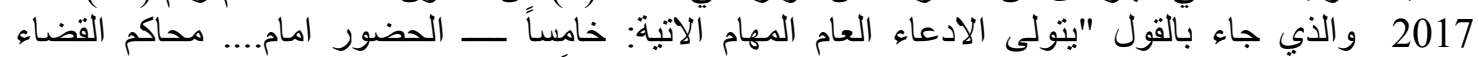

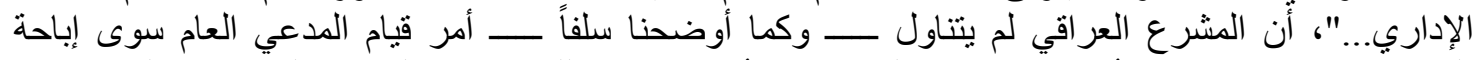

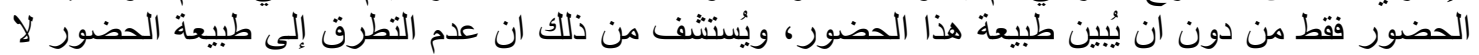

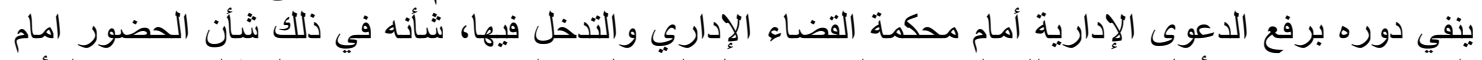

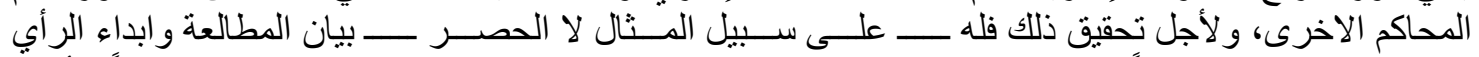

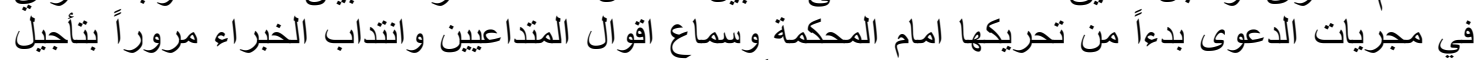

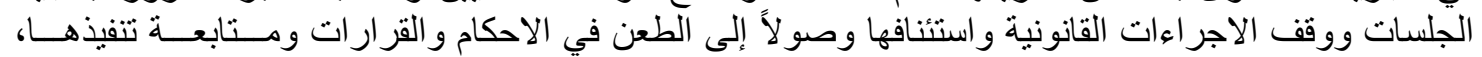

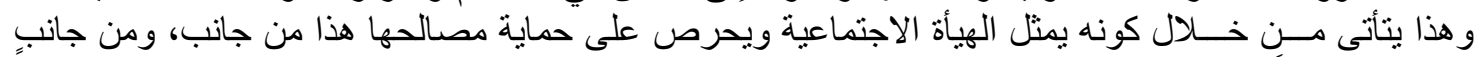

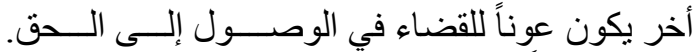

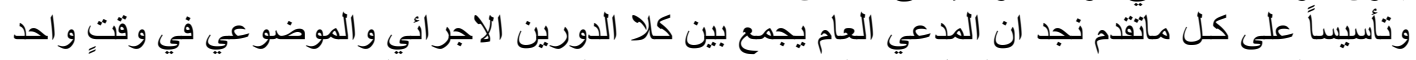

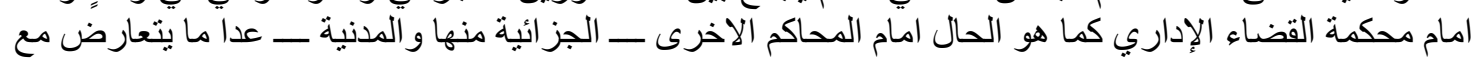
طبيعة هذه المحكمة.

ومن الجدير بالذكر ونحن نتحدث عن دور المدعي العام أمام محكمة القضاء الإداري، نجد لزئ لزاماً علينا

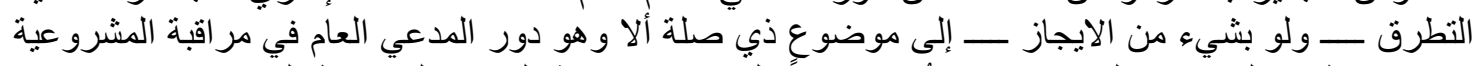

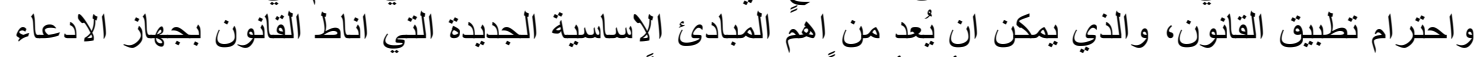

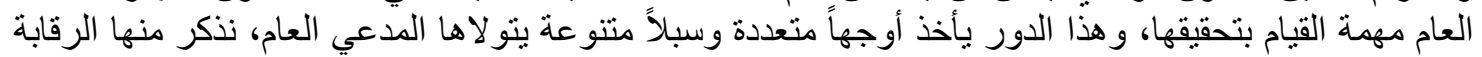

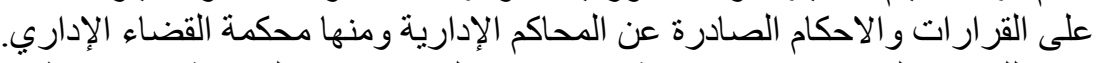

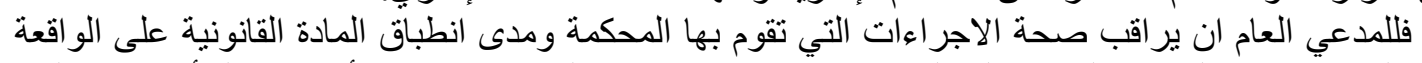

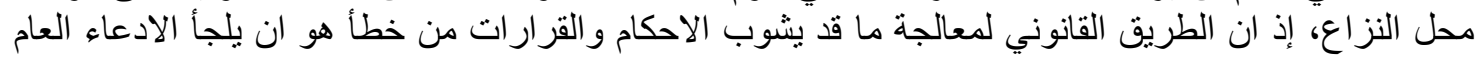
إلى الطعن حسبما قرره القانون من طرق الطع الطعن.

\section{المبحث الثالث}

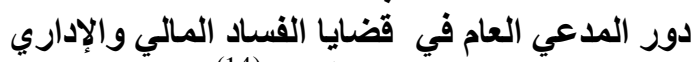

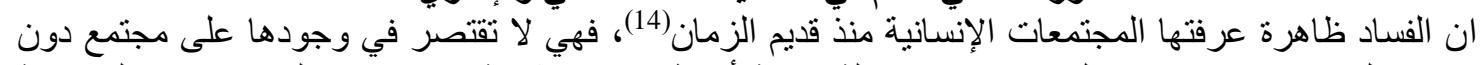

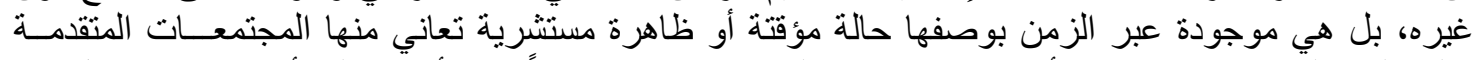

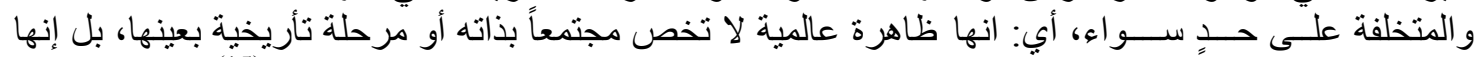

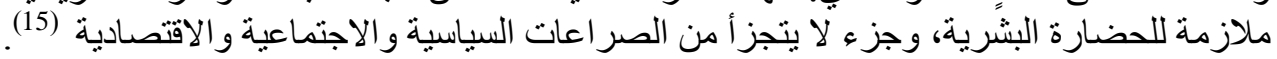

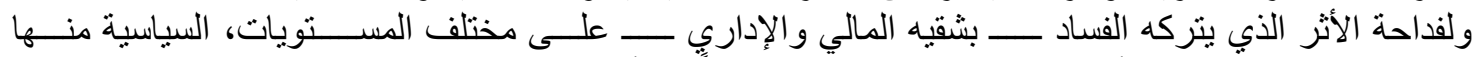

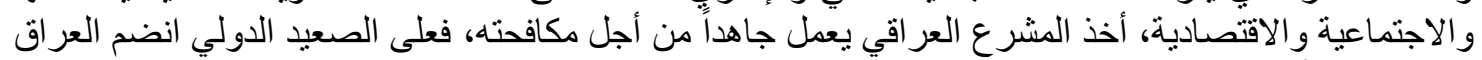

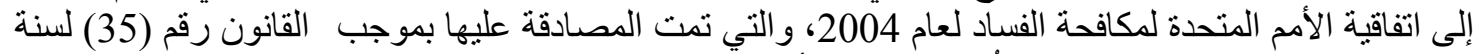

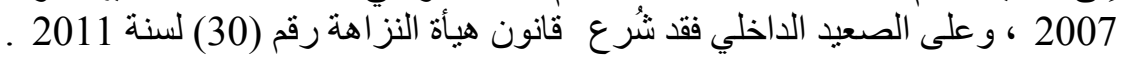




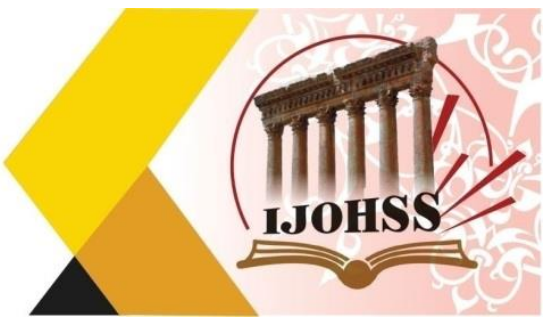

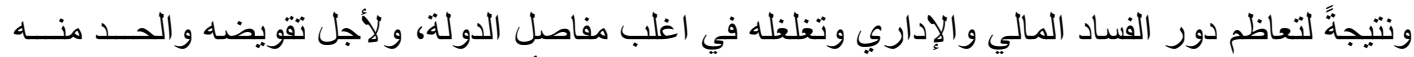

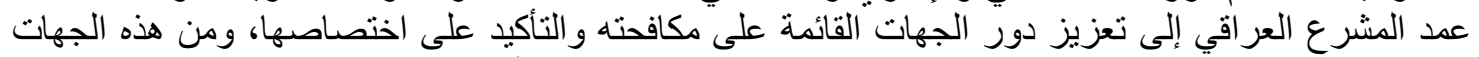

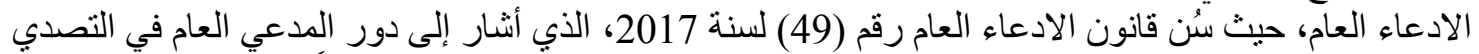

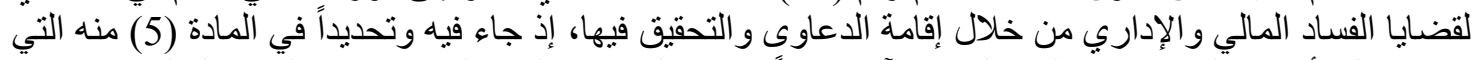

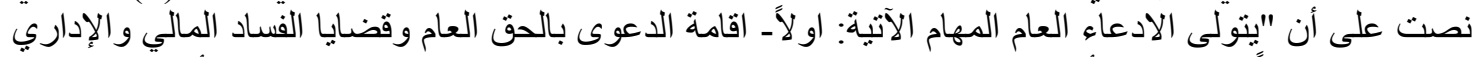

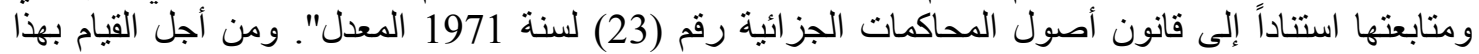

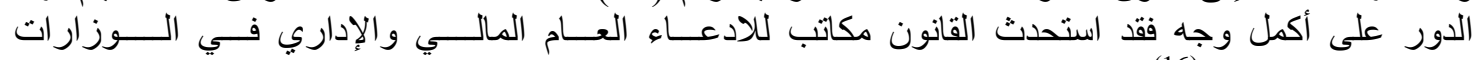

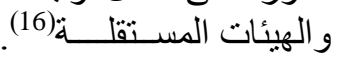

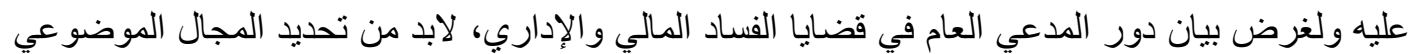

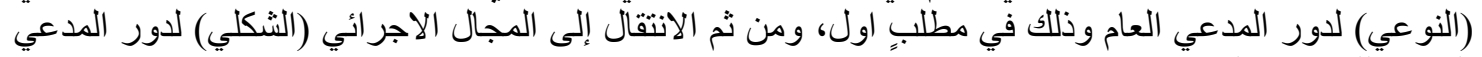
العام وذللك في مطلبٍ ثانِ.

\section{المطلب الأول}

\section{المجال الموضوعي لدور المدعي العام لمان}

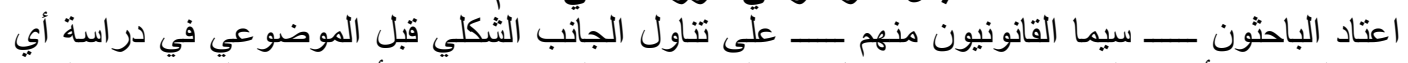

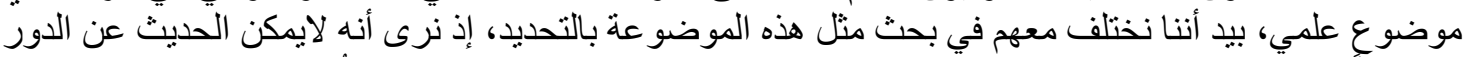

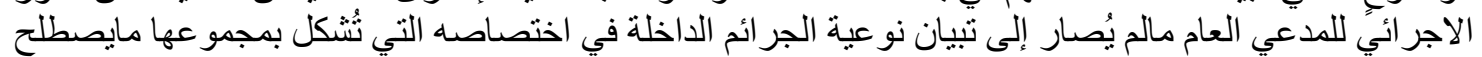

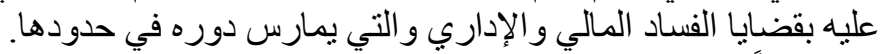

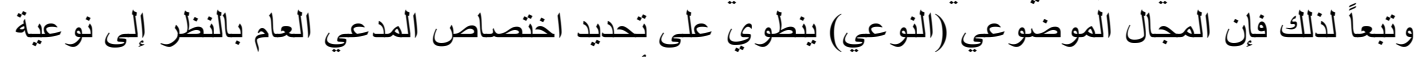

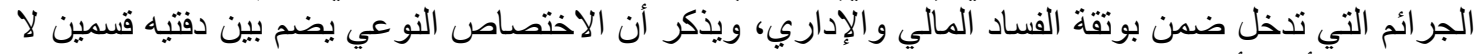

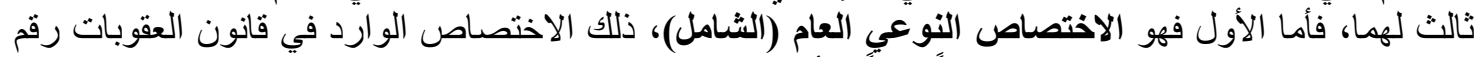

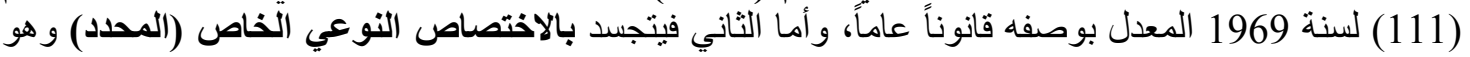

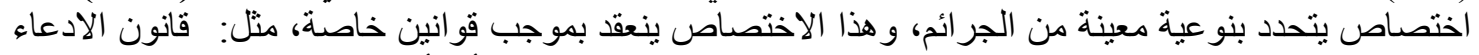

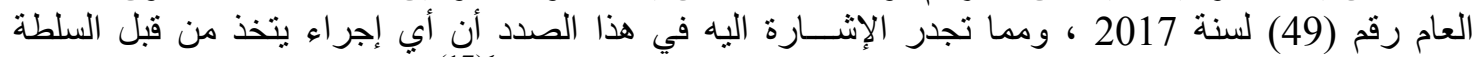

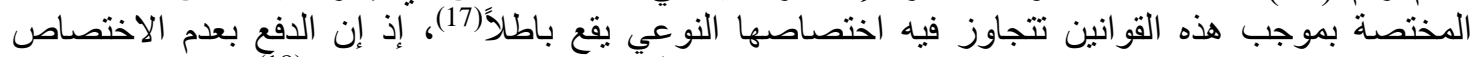

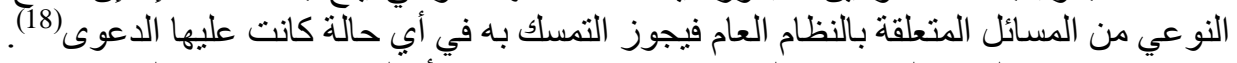

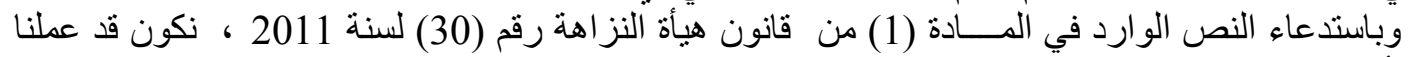

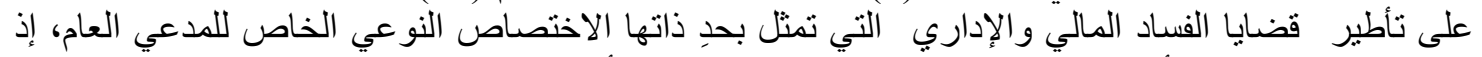

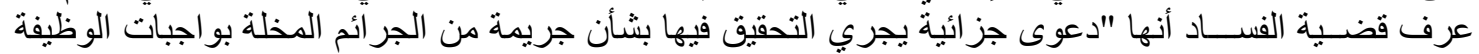

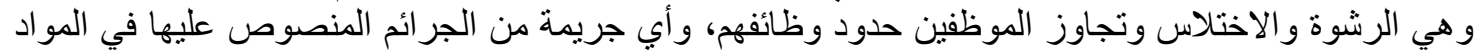

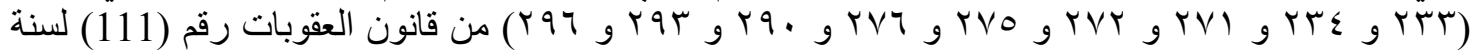

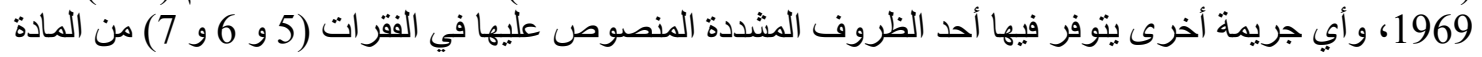

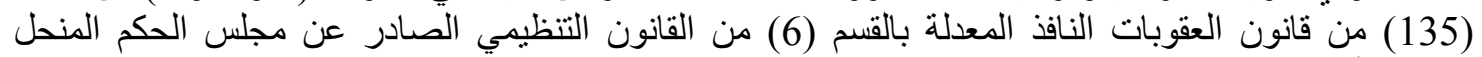

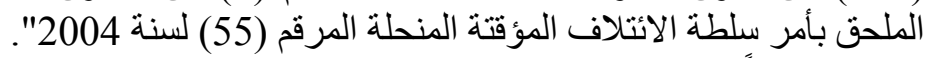

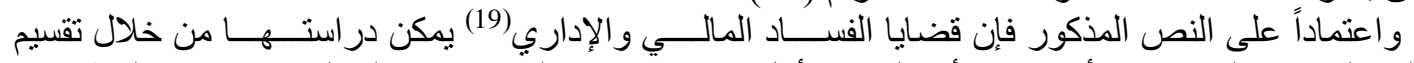

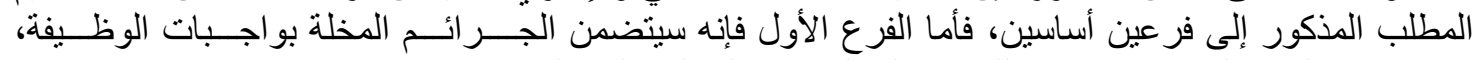

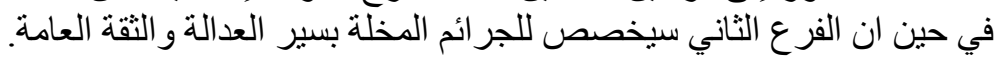

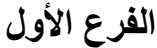

\section{الجرائم المخلة بواجبات الوظيفة}

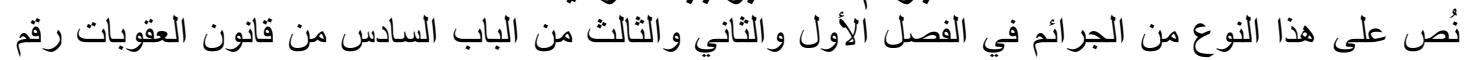

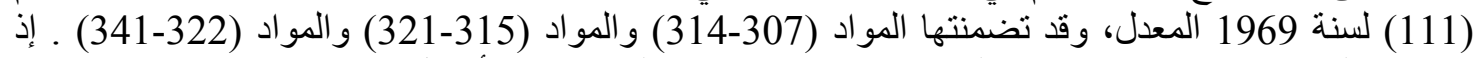

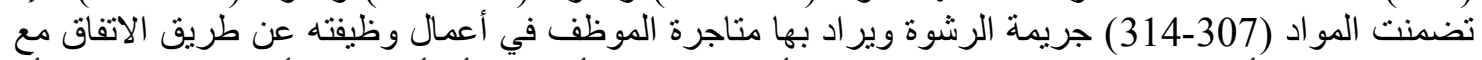

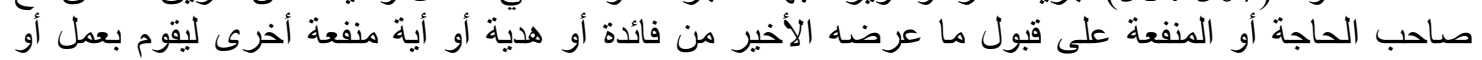




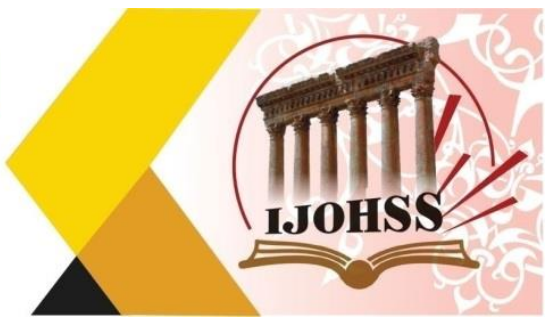

الامتتاع عن القيام بعمل يدخل في حكم وظيفته أو دائرة اختصاصه أو زعم ذلك (20)، إذ تقتضي جريمة الرشوة

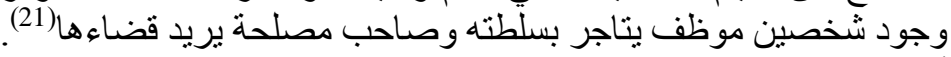

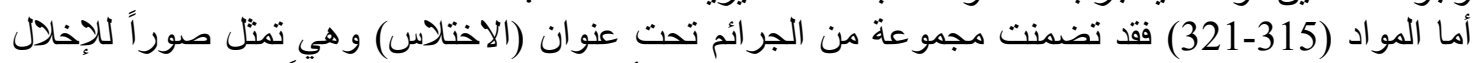

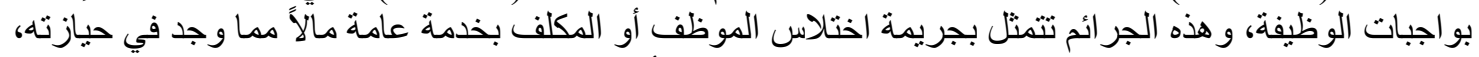

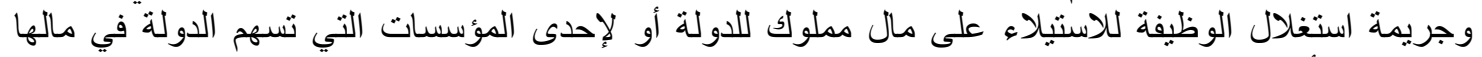

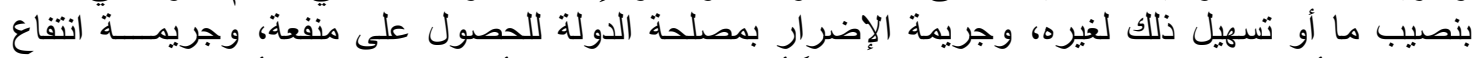

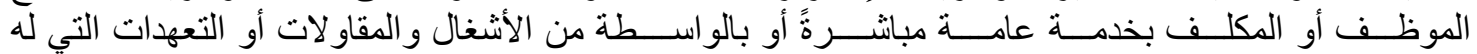

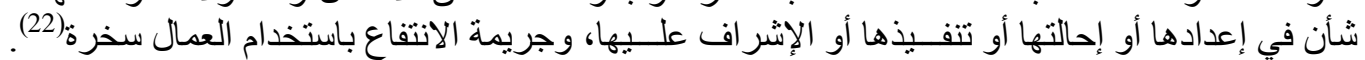

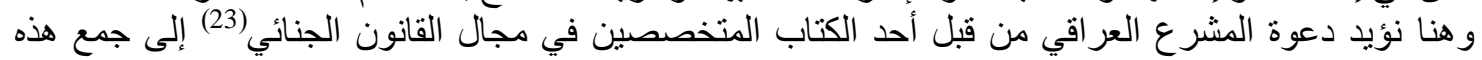

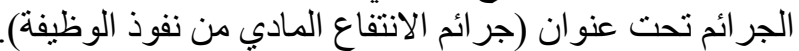

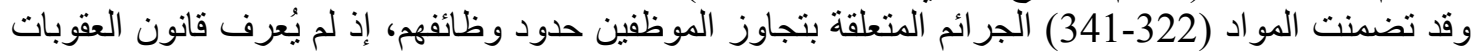

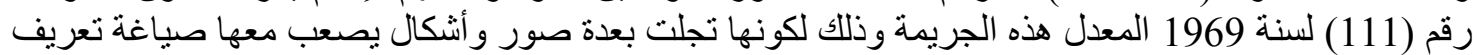

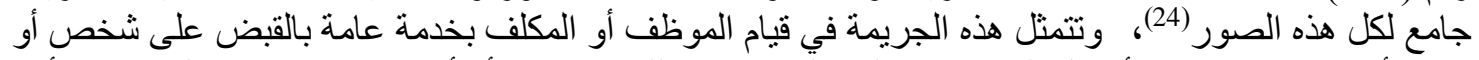

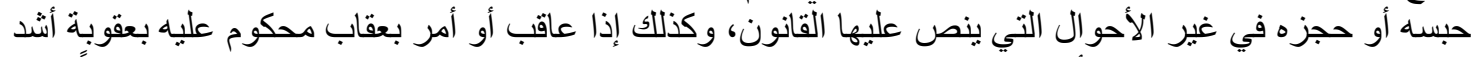

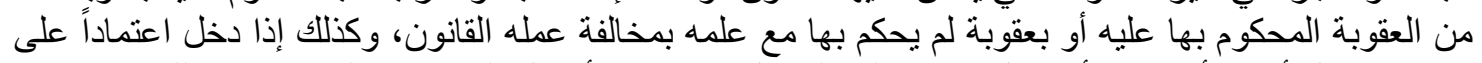

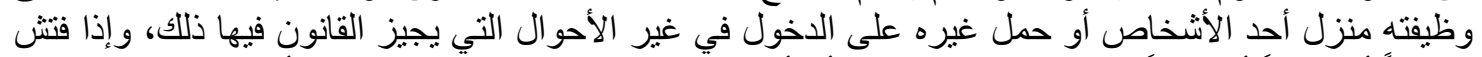

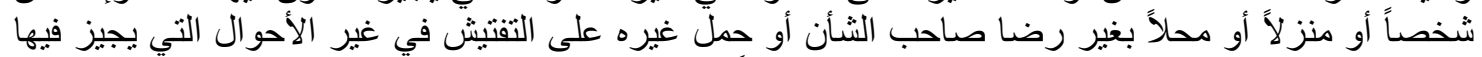

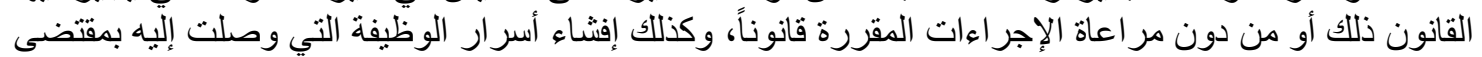

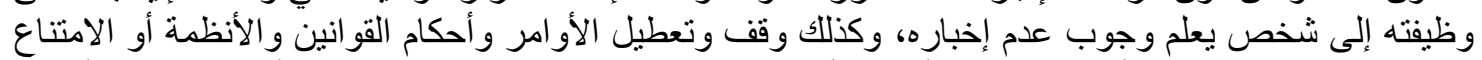

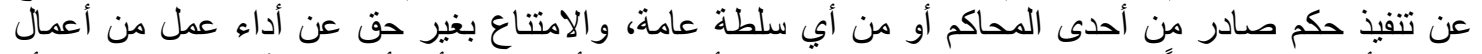

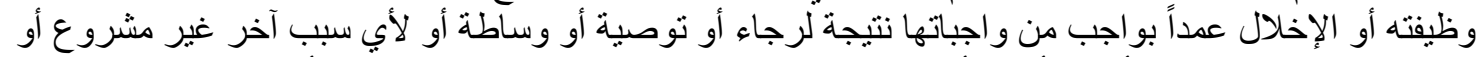

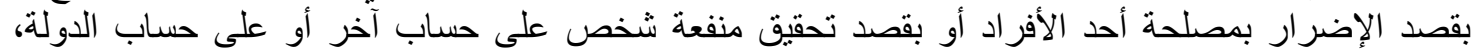

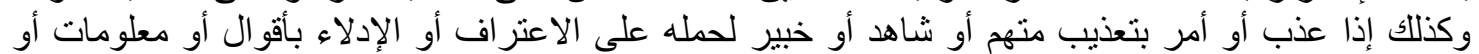

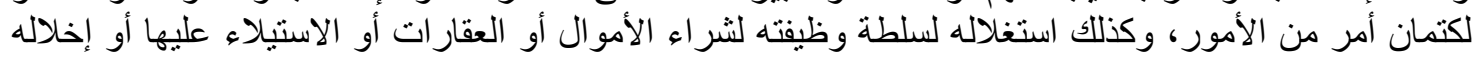

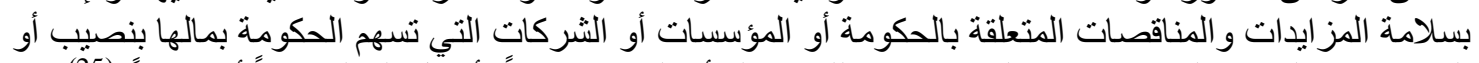

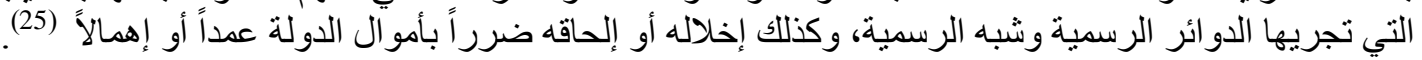

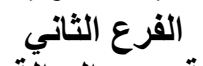

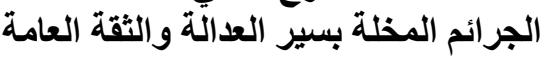

سيتم بحث الجر ائم المخلة بسير العدالة وكذللك المخلة بالثقة العامة بعد توزيعها إلى نقطتين منفصلتين وهما:

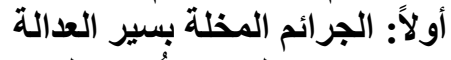

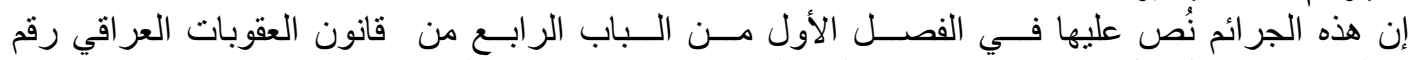

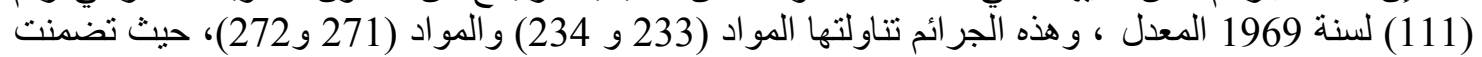

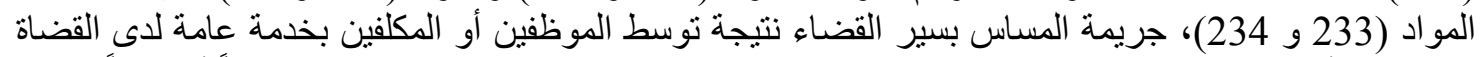

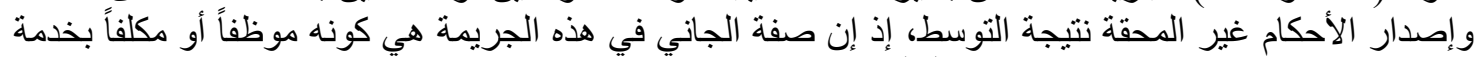

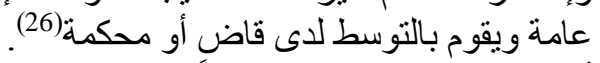

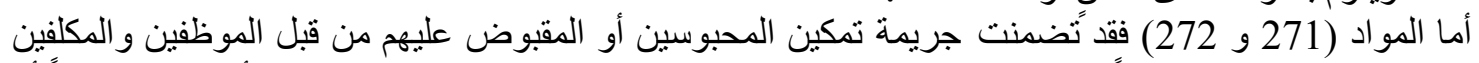

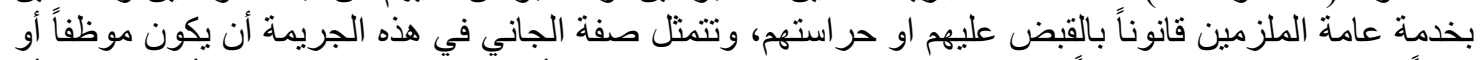

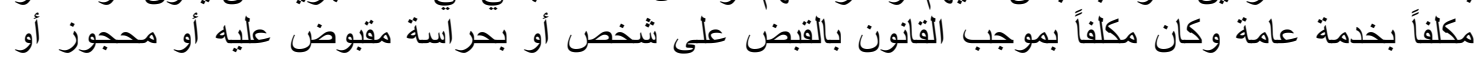

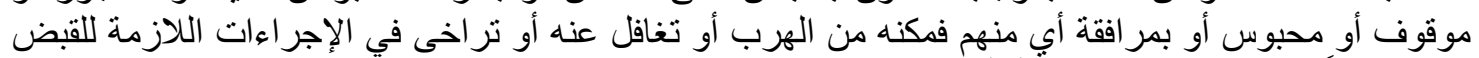

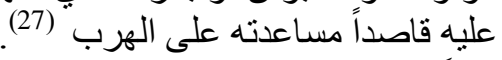

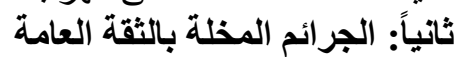

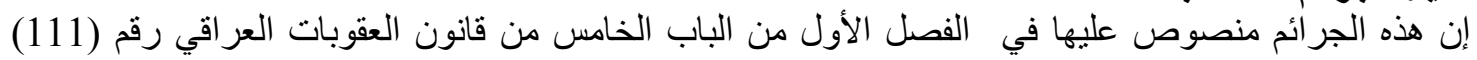

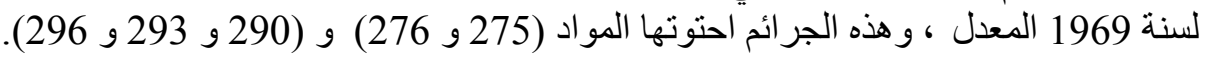




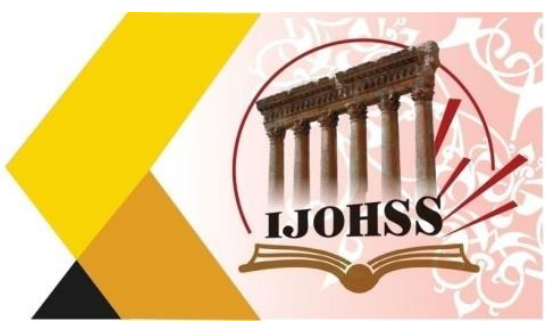

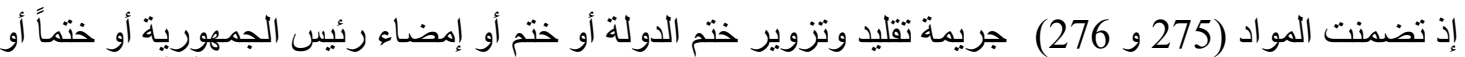

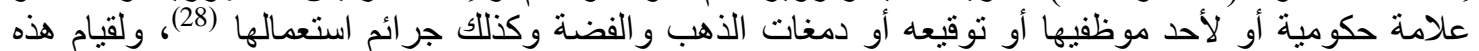

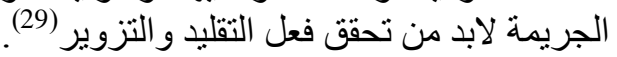

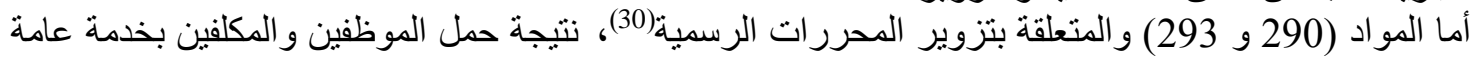

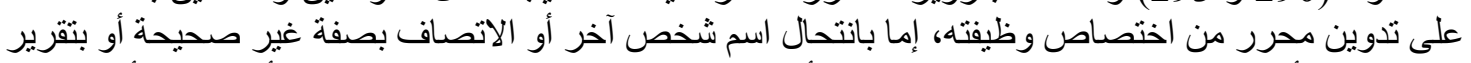

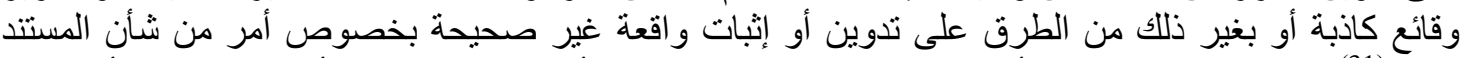

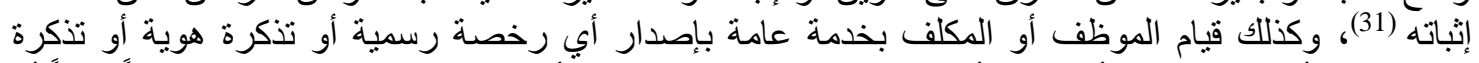

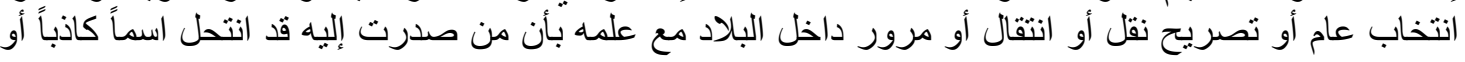
شخصية كاذبة أنغابة

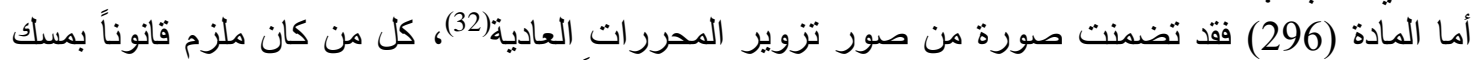

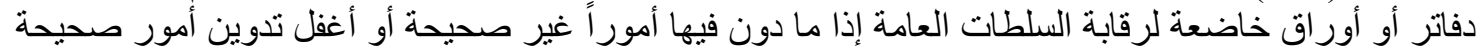

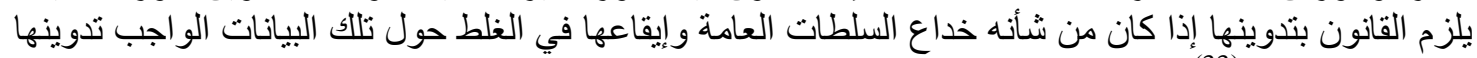

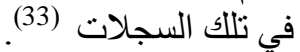

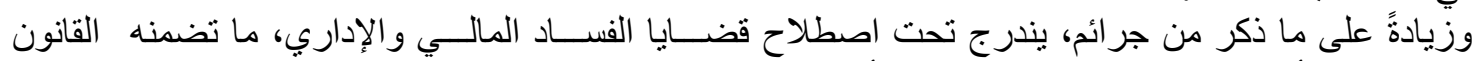

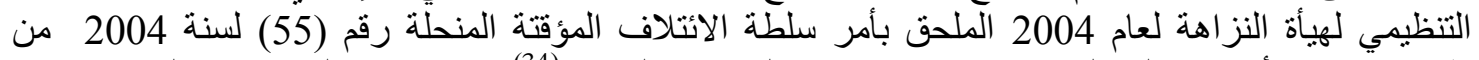

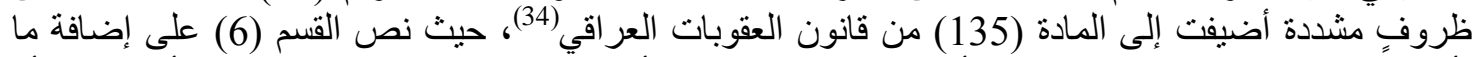

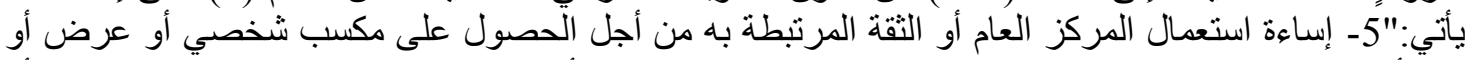

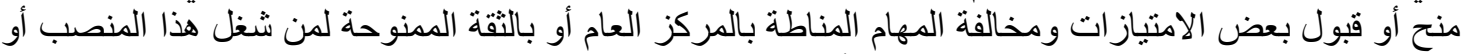

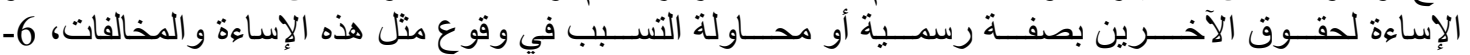

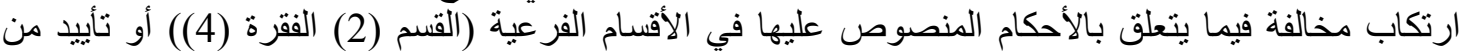

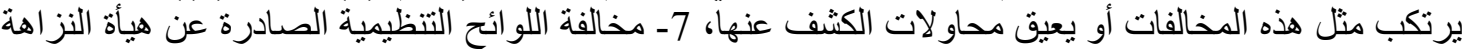

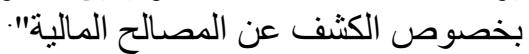

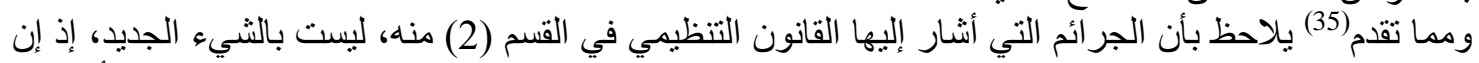

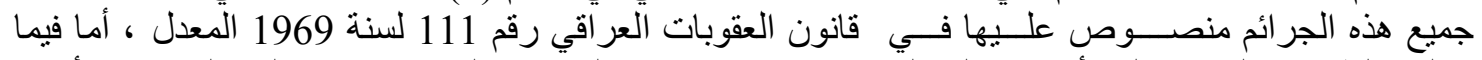

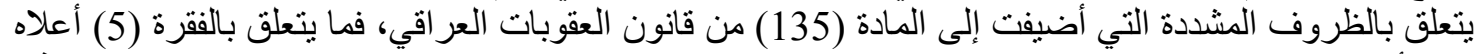

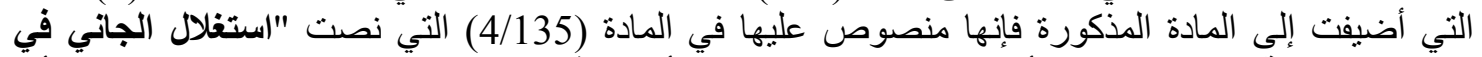

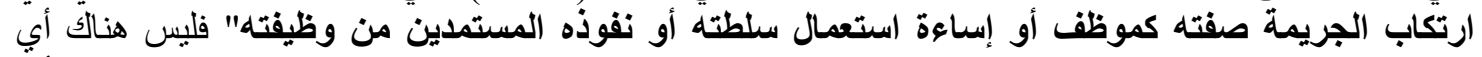

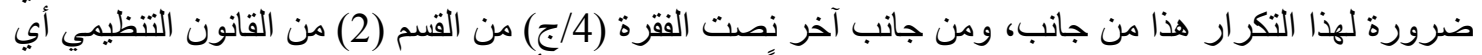

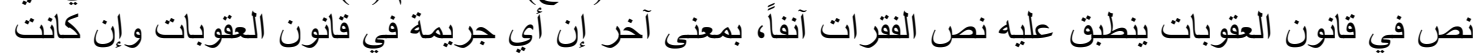

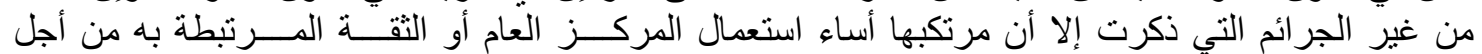

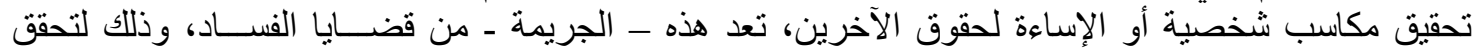
ظرف مشدد فيها يدخلها في هذا النوع من القضاعـايا.

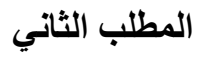

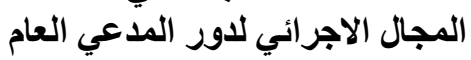

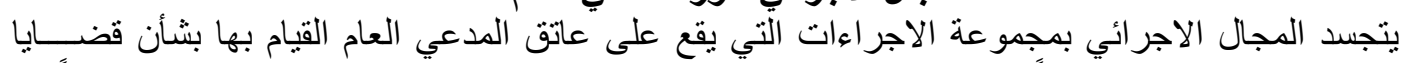

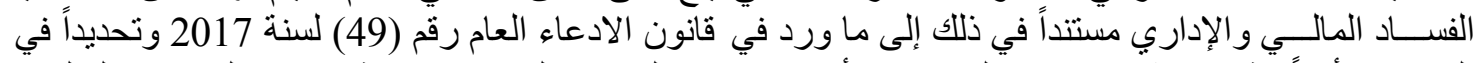

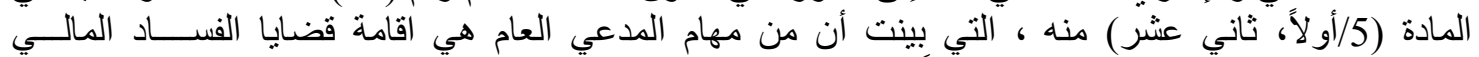

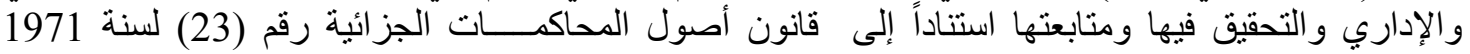

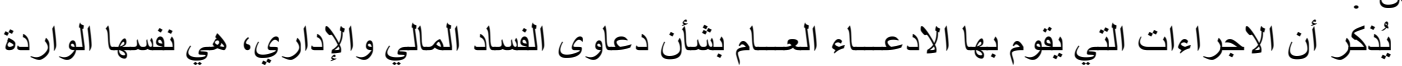

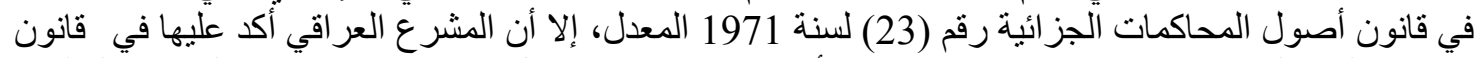

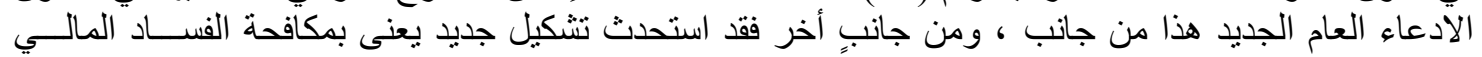

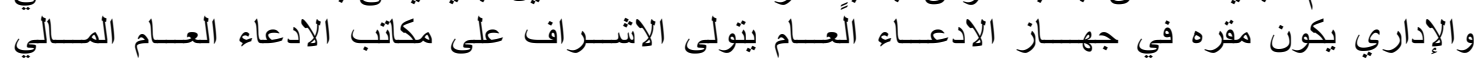




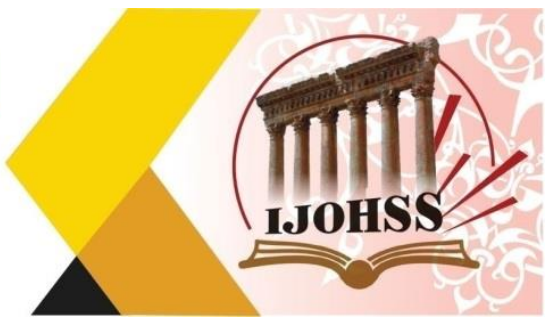

و الإداري في الوزارات و الهيئات المستقلة، ويمكن ان يُعزى اهتمام المشرع بذلك إلى استشر اء جرائم الفساد في إني

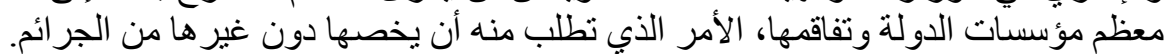

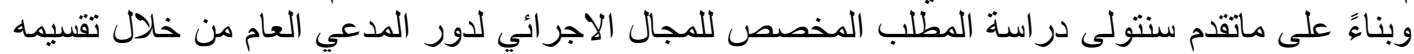

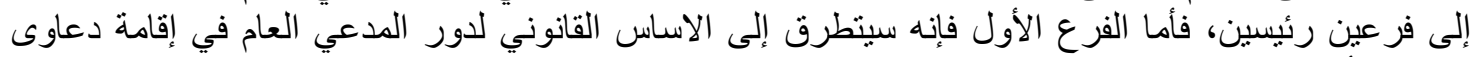

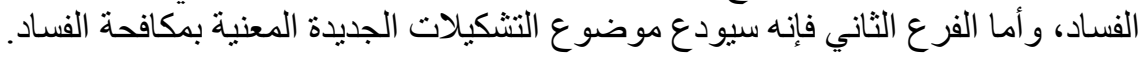

\section{الفرع الأول}

\section{الاساس القانوني لدور المدعي العام في إقامة دعاوى الفاول الفساد}

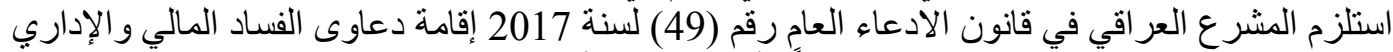

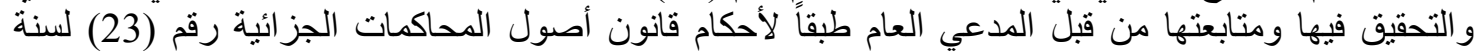

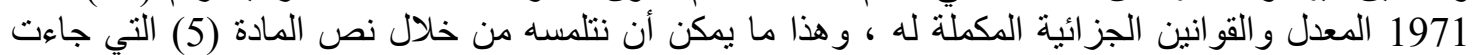
بالقول "ينولى الادعاء العام المهام الآتية:

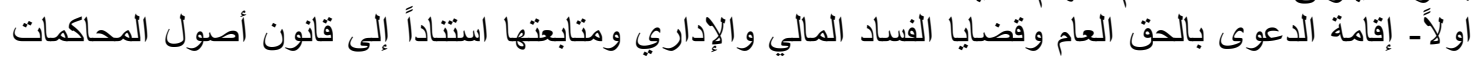

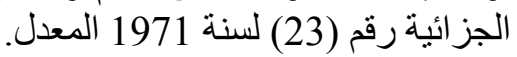

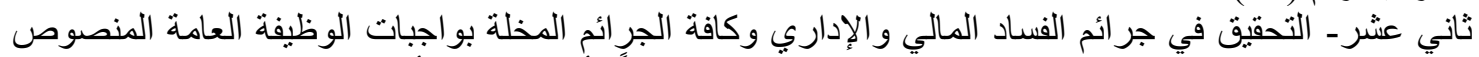

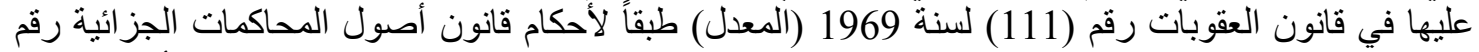

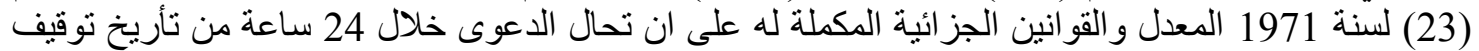

$$
\text { المتهم إلى قاضي التحقيق". }
$$

وطالما اشترط المشرع العراقي مزاولة المدعي العام لاختصاصه بتحريك دعوى الفساد المالي والإداري

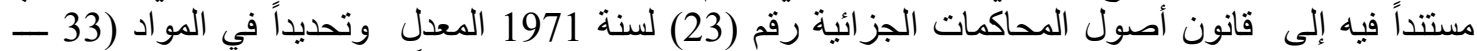

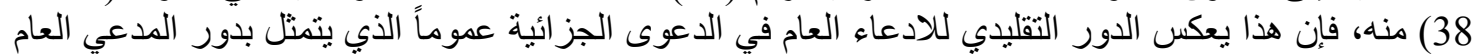

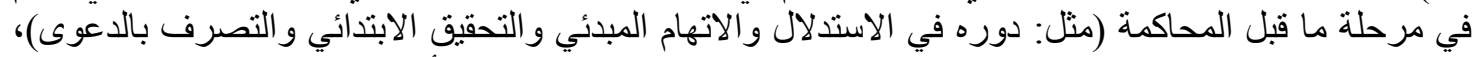

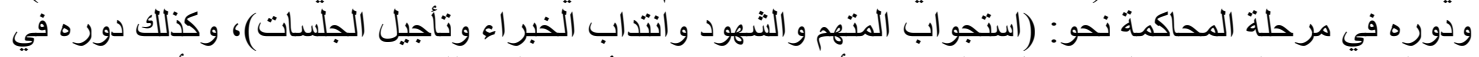

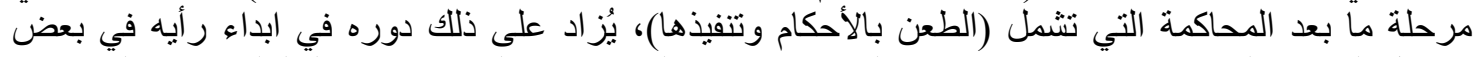

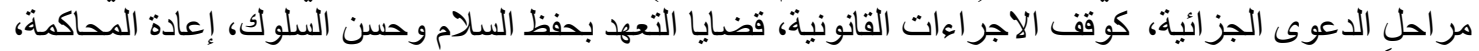

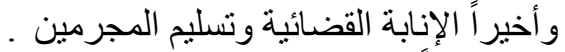

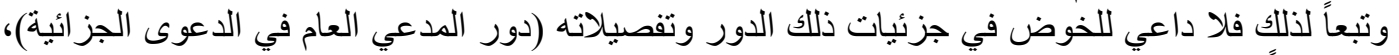

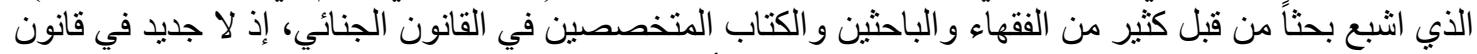

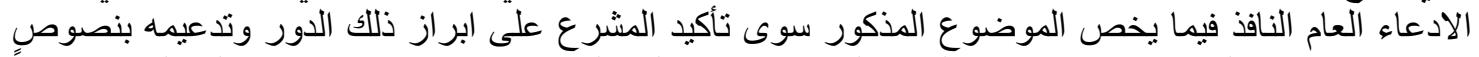

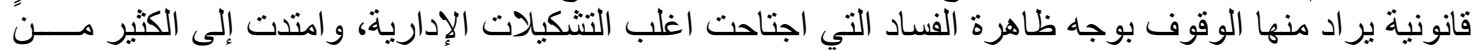

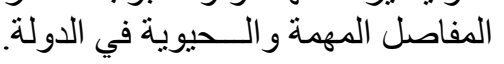

\section{التثكيلات الجديدة المعنية بمكافحة الفساد الفئي}

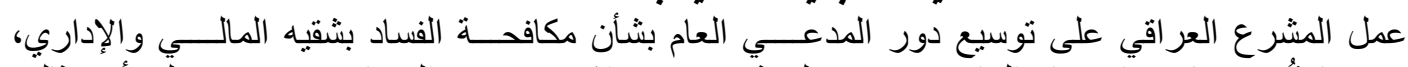

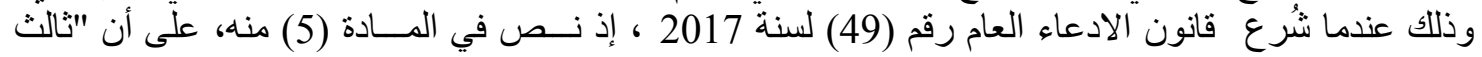

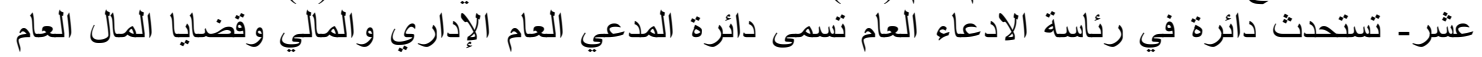

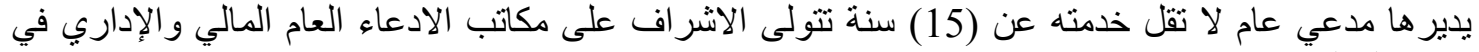

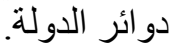
رابع عشر - يؤسس مكتب للادعاء العاء العام المالي و الإداري في الوزارات و الهيئات المستقلة يمارس اختصاصه طبقاً لأحكام الفقرة حادي عشر من هذه المادة".

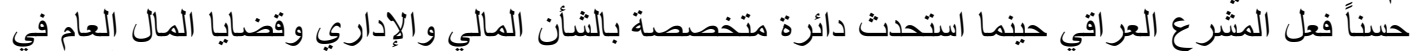

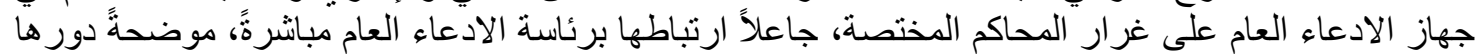




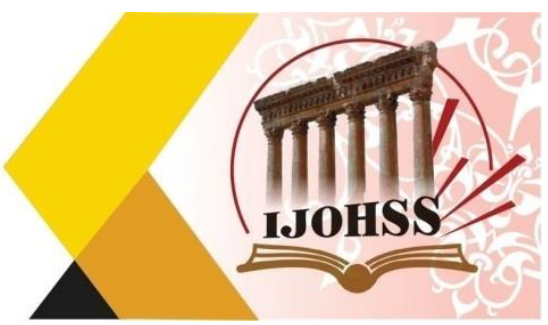

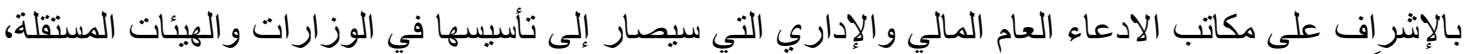

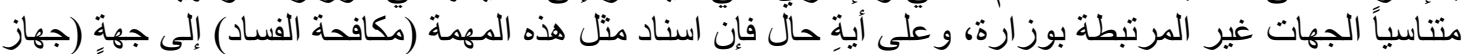

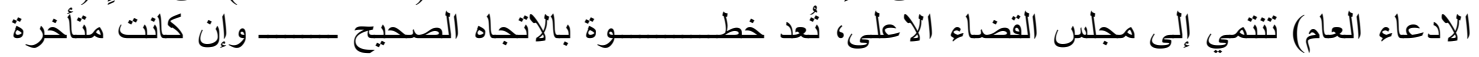

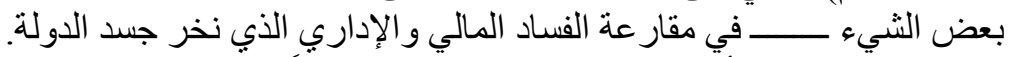

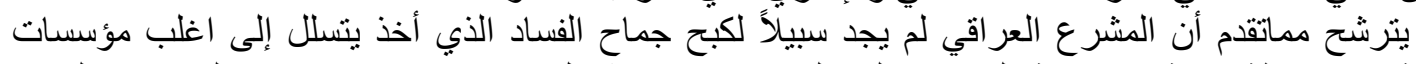

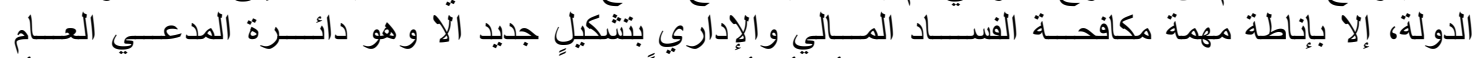

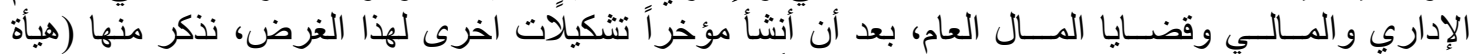

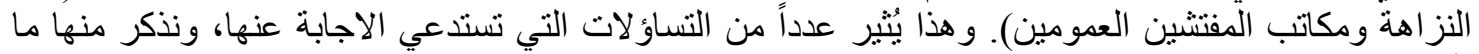

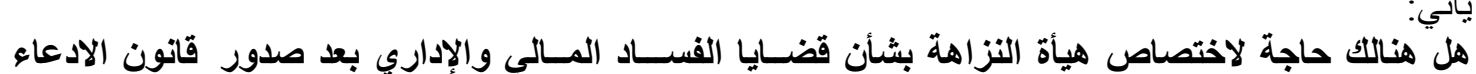

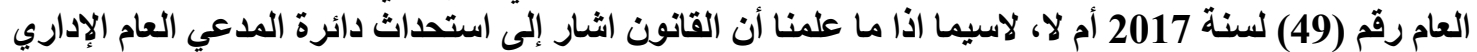

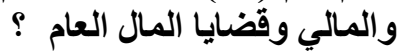

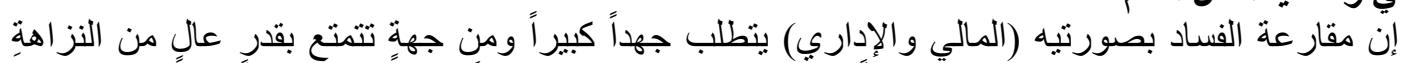

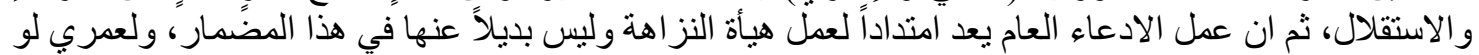

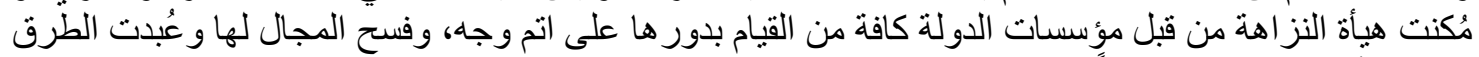

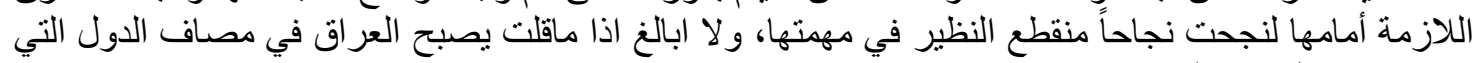

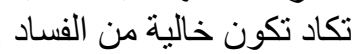

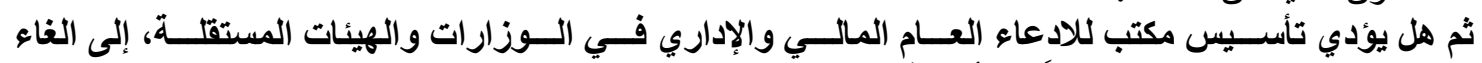

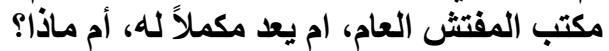

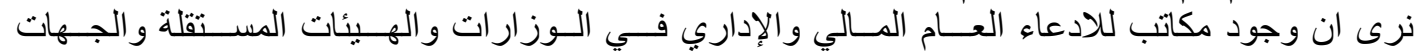

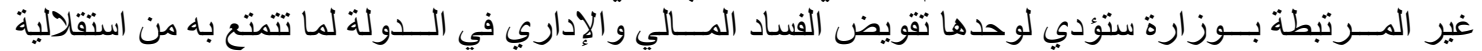

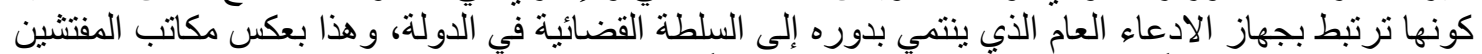

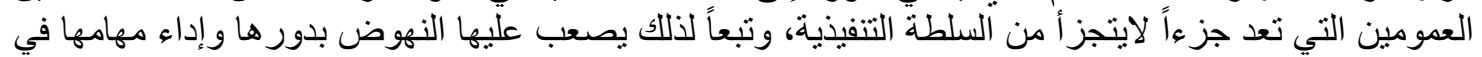

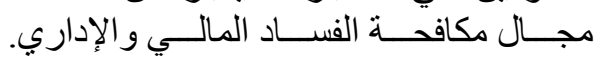

وأخيراً هل أن تعدد التثكيلات والجهات التي تُعنى بمكافحة الفساد المالي والإداري في الاولة حالةُّ صحية أم لا؟

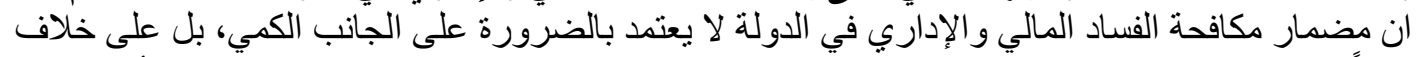

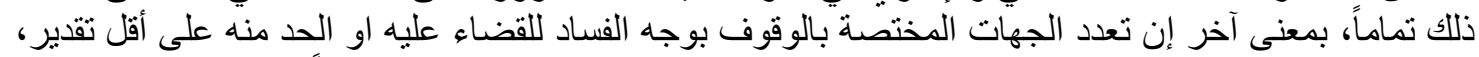

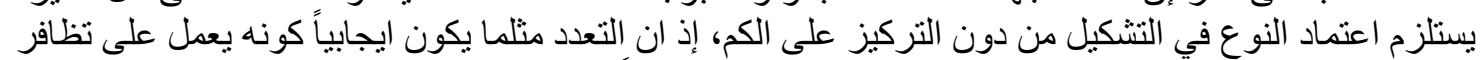

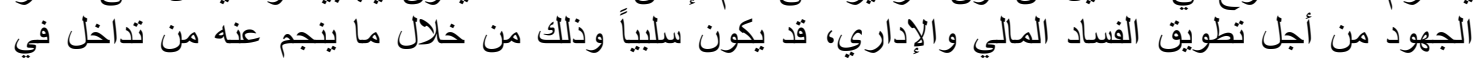

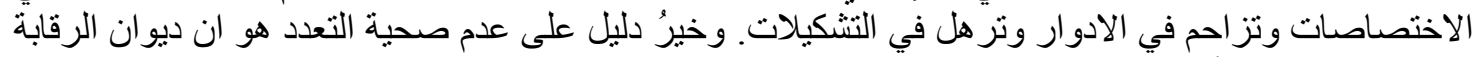

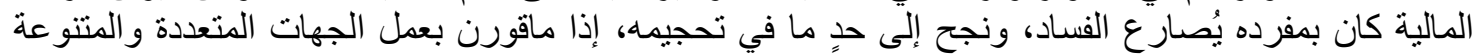

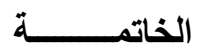

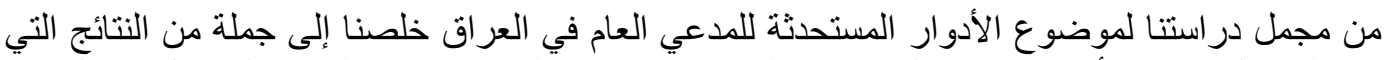

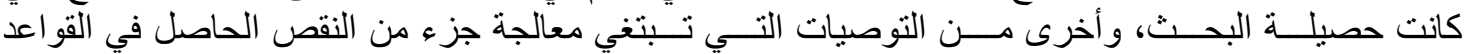

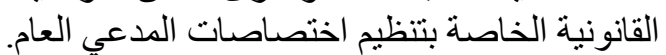

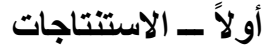

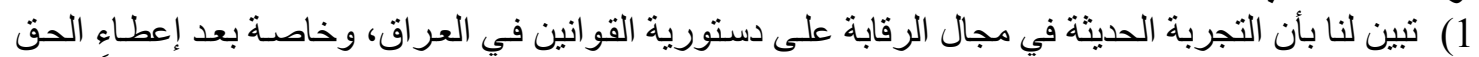

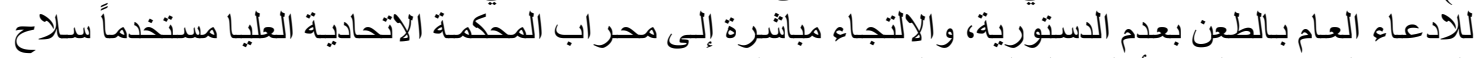

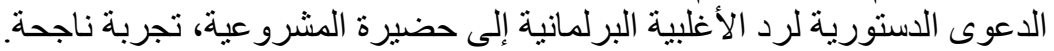




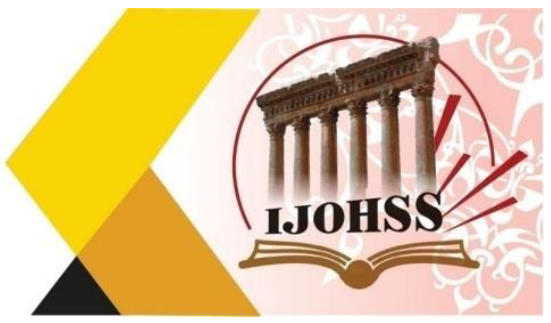

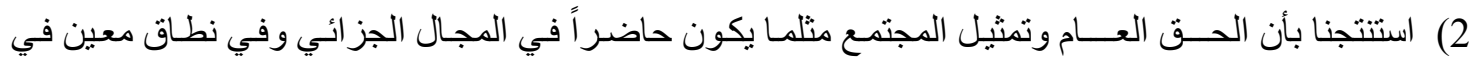

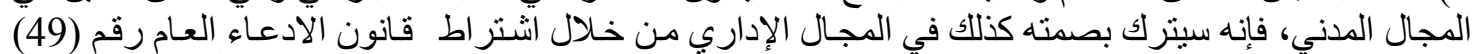

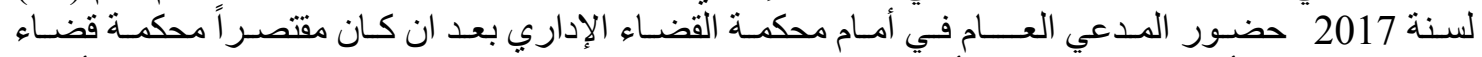

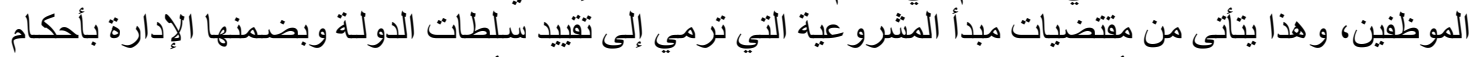

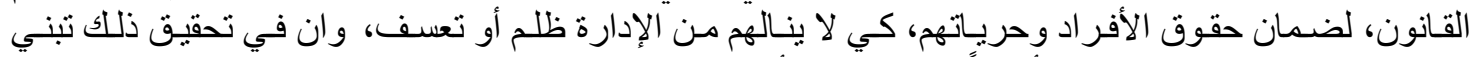

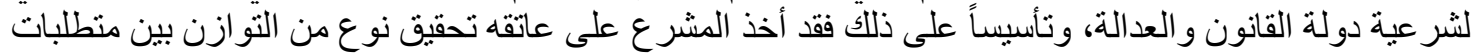

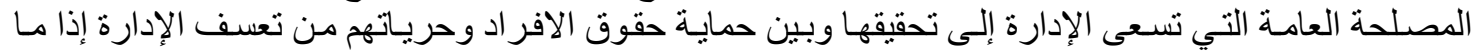

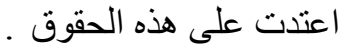

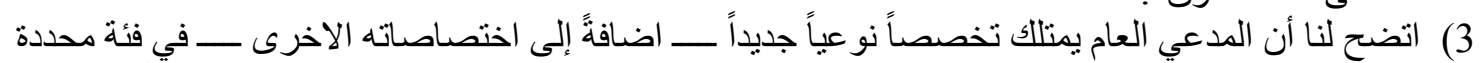

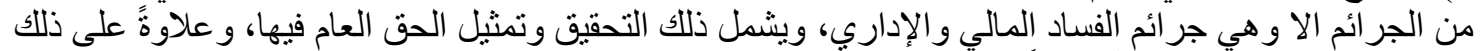

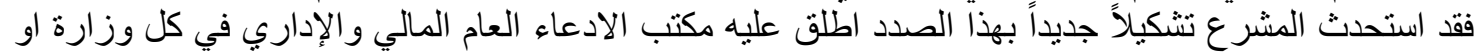

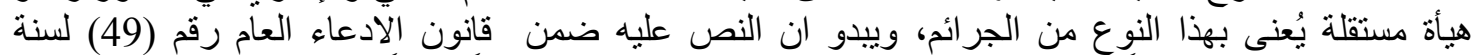

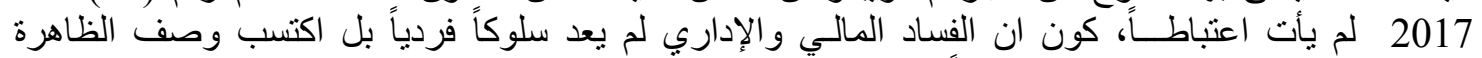

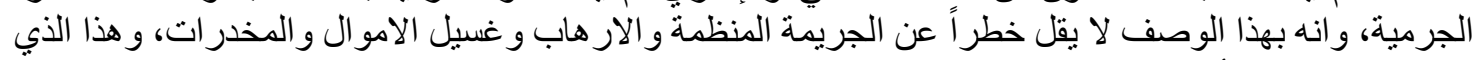

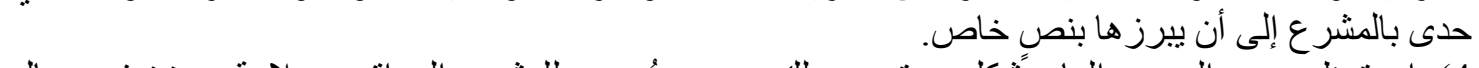

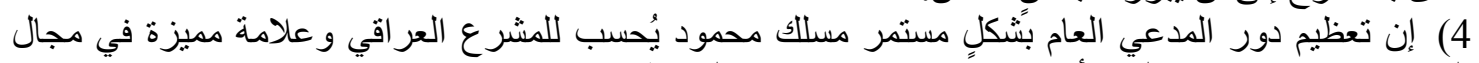

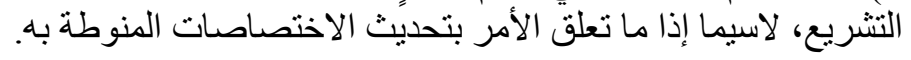

$$
\text { ثانياً - التوصيات }
$$

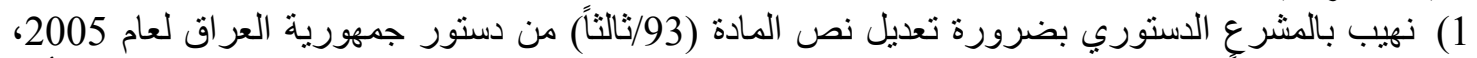

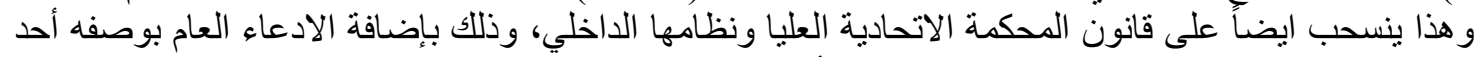

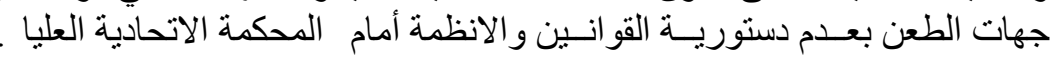

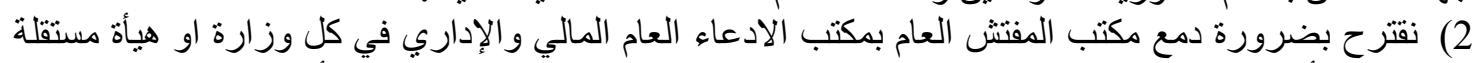

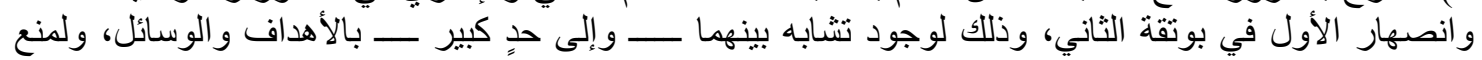
الازدو اج في العمل الرقابي.

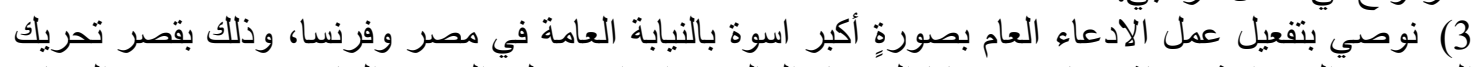

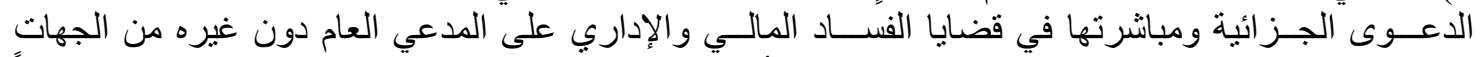

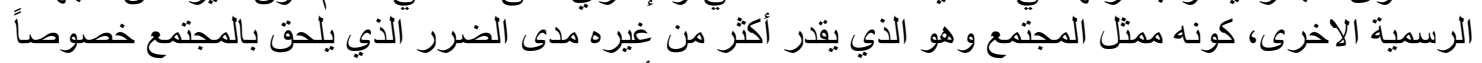

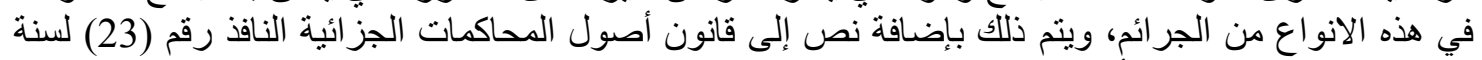

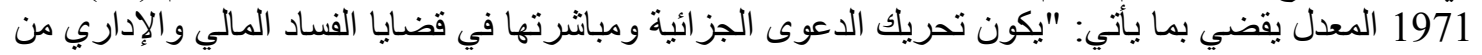

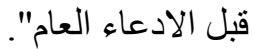

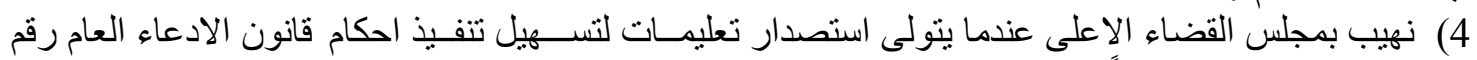

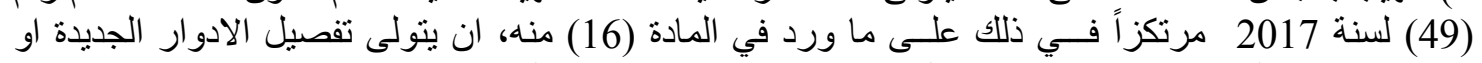

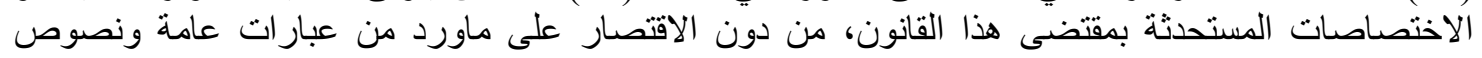
سطحية. 


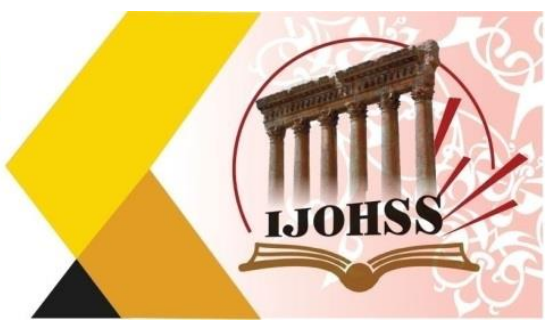

الهوامش

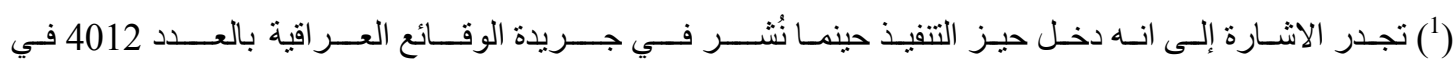
. 2005/12/28

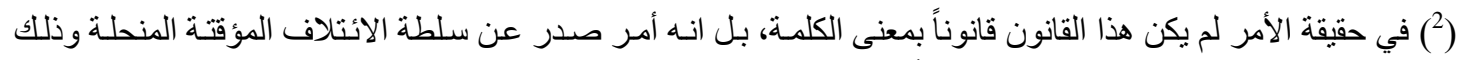

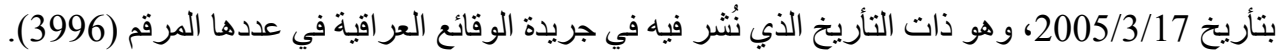

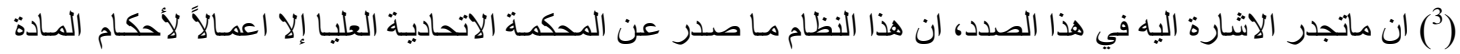

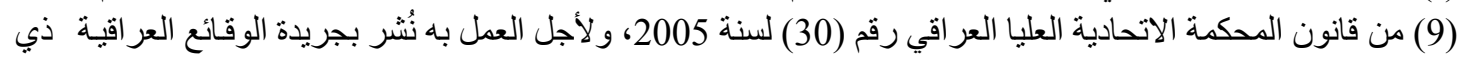

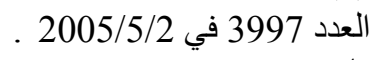

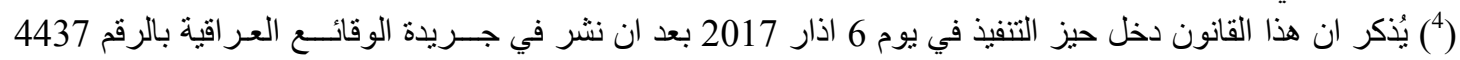

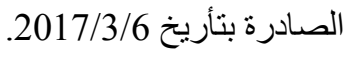

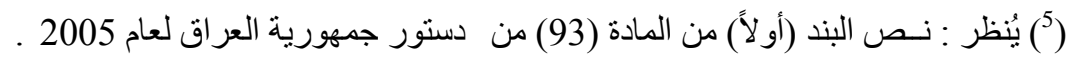

$$
\begin{aligned}
& \text { (6) يُظر : نص البند (حادي عشر) من المادة (5) من قانون الادعاء العام رقم (49) لسنة } 2017 \text { ـ }
\end{aligned}
$$

(7) يُنكر ان قانون الادعاء العام رقم (49) لسنة 2017 دخل حيز التنفيذ في يوم 6 اذار $2017 / 6$ العار 2017 وذللك حينما نشر في جريدة

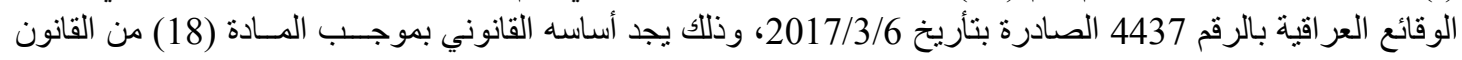
المذكور التي جاءت بالقول "يففذ هذا القانون من تأريخ نشره في الجريدة الرسمية" .

(8) صلاح خلف عبد، المحكمة الاتحادية العليا في العر اق تثكبلها واختصاصاتها (در اسة مقارنة)، رسالة ماجستير، كلية

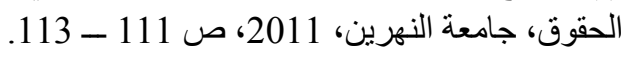

2006 / 200

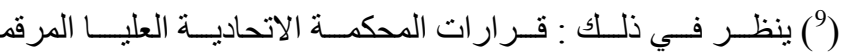

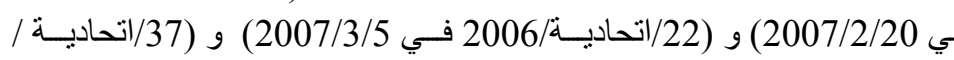

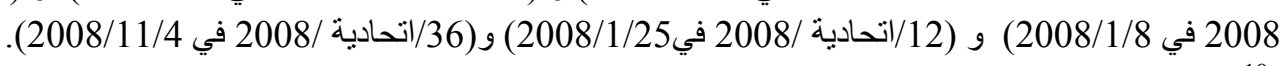

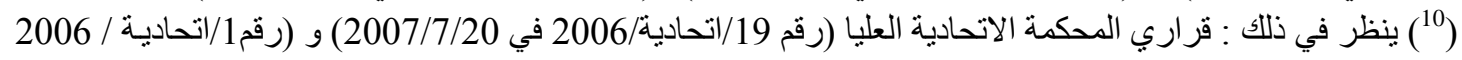
في 2006/5/29.

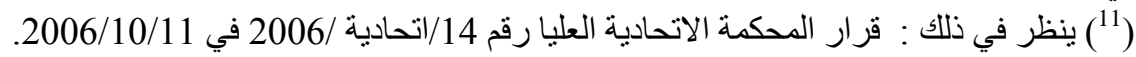

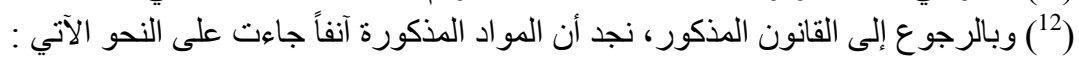
المادة (44) (12) "1" - 1" كل دعوى يجب ان تقام بعريضة.

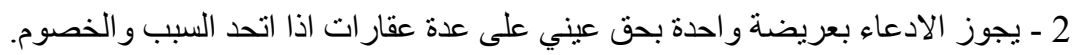

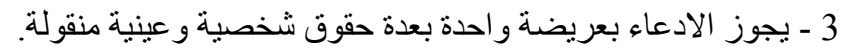

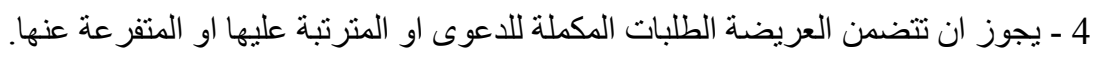

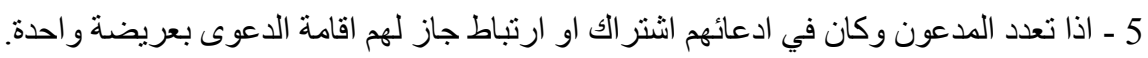

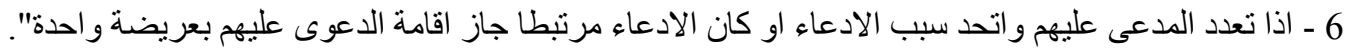
المادة (45) "تقام الدعوى باعتبار قيمـة الطلب الاصلي يوم رفعها بصـرف النظر عمـا يكون مستحقا قبل ذلك او بعده من الفو ائد

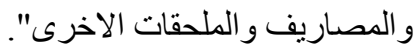

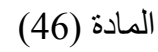
"يجب ان تشنمل عريضة الدعوى على البيانات الاتية : 


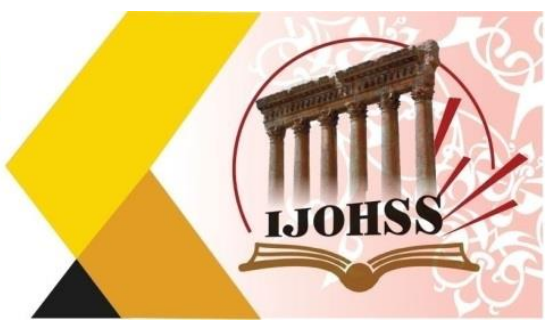

1 - 2 - اسم المحكمة التي تقام الدعوى امامها.

2 - 2 - تأريخ تحرير العريضة.

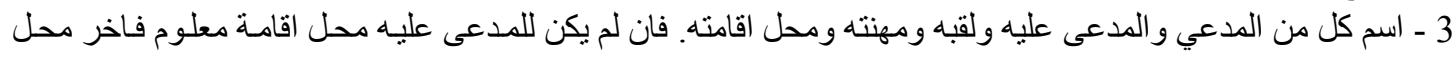
كان به.

4 - بيان المحل الذي يختاره الددعى لغرض التبليغ.

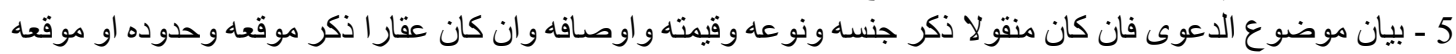

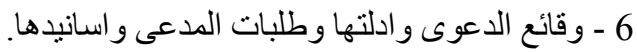
7 - توقيع الددعى او وكيله اذا كان الوكيل مفوضا بسند مصدق التهات عليه من جهة مختصة".

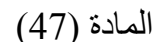
"أعتبر نص المادة (47) من القانون الفقرة (1) للمادة ذاتها، و أضيفت إليها الفقرتين (3،2) بموجب قرار مجلس قيادة

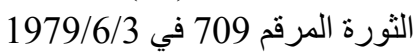

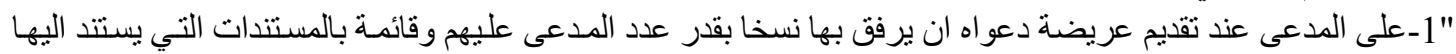

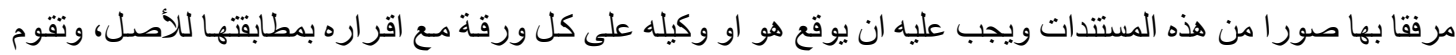
المحكمة بتبليغها للخصم.

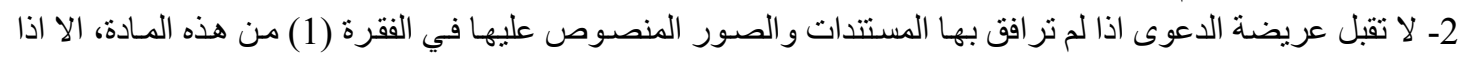

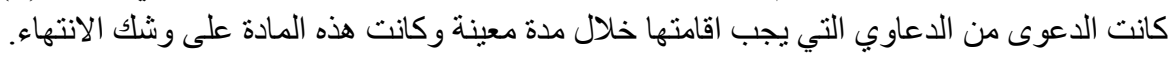

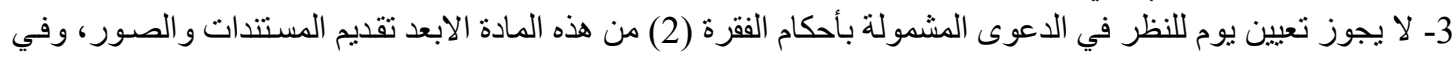

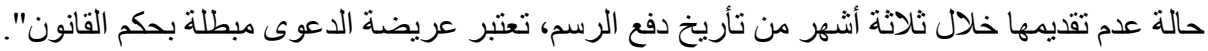

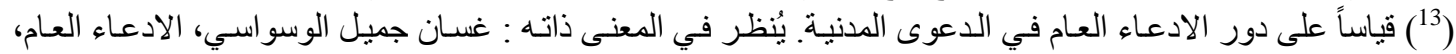

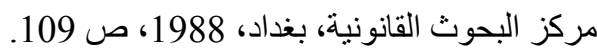

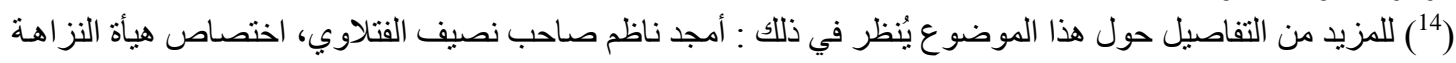

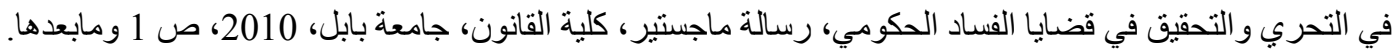
$\left({ }^{15}\right)$ Mohammad Mohabbat Khan, Pollitical and Administrative corruption, Englewood cliffs, $\mathrm{Nj}$, Princeton Hall, inc, 2004, p.1 . and Mari - Liss Liiv, The causes administrative corruption, University of Tartu, Faculty of social sciences, Thesis for the master's degree in public administration, 2004, p 102.

(16) يُنظر في ذللك : البنود (ثاني عشر، ثالث عشر ، رابع عشر ) من المـادة (5) من قانون الادعاء العام رقم (49) لسنة

(17) ينظر : د. سليمان عبد المنعم، أصول الإجراءات الجنائية، الكتاب الثاني، ط1، منشورات الحلبي الحقوقية، بيروت،

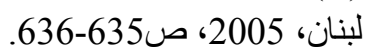
(18) ينظر : جندي عبد الملك، مجموعة المبادئ الجنائية، ط2، دار المنشورات القانونية، بيروت، لبنان، دون سنة طبع،

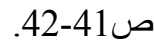

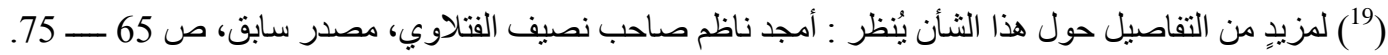

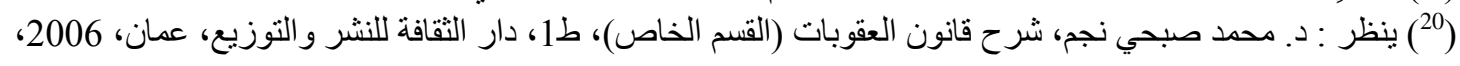
(21 التفاصيل أكثر حول هذا الموضوع تُنظر : د. و اثبة داود السعدي، قانون العقوبات (القسم الخاص)، المكتبة الوطنية،

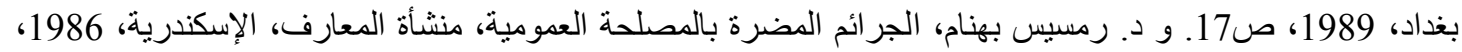
ص8. و د. محمد زكي أبو عامر ود. سليمان عبد المنعم، قانون العقوبات القسم الخاص، منشورات الحلبي الحقانة الحقوقية،

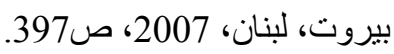




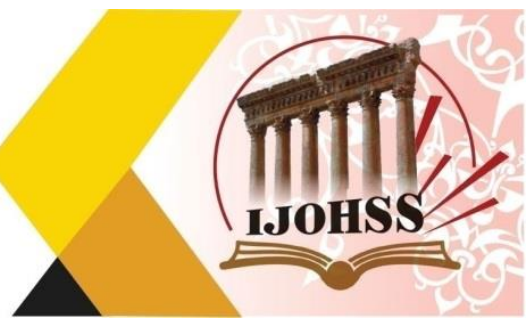

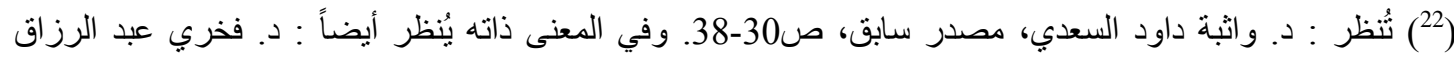

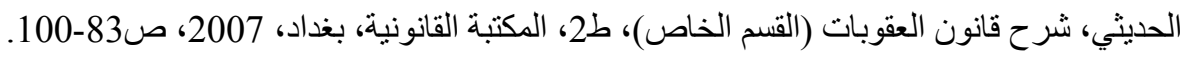

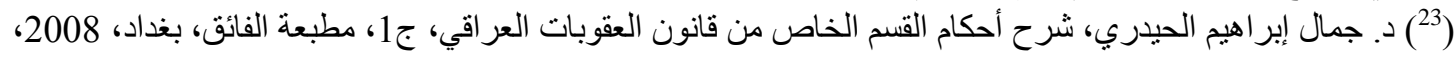
صاصن :126-124. (24) ينظر : علي السباك، جر ائم الفساد الإداري المعاقب عليها في القانون العر اقي، بحث منشور في مجلة دليل الموظف

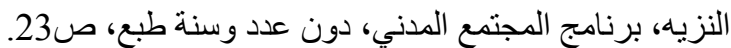

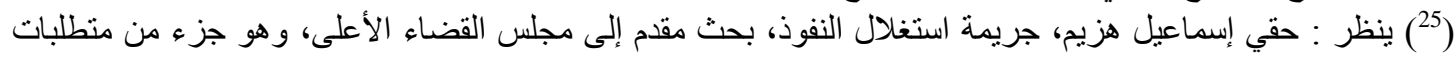

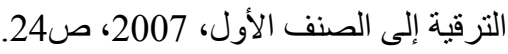

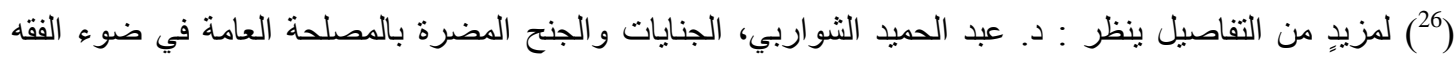

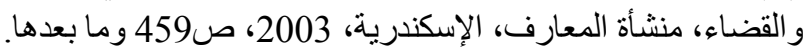

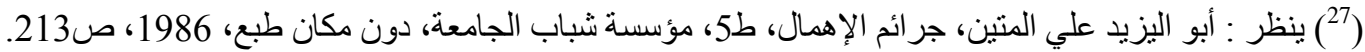

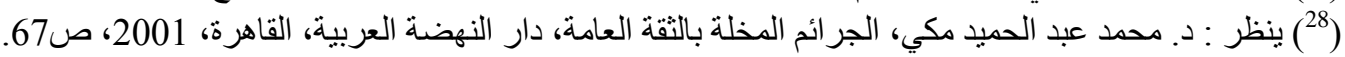

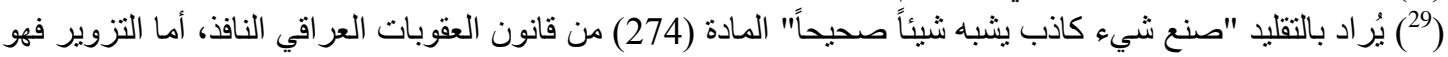

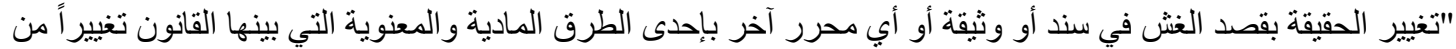

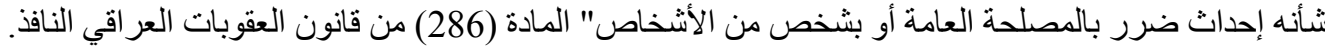

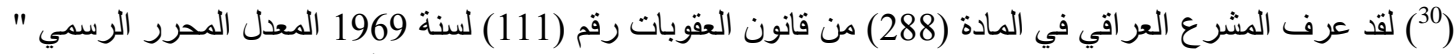

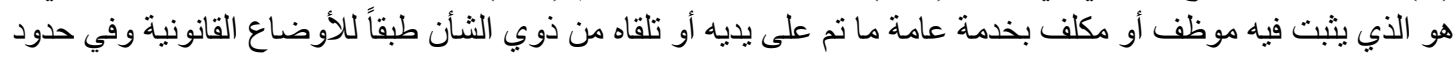

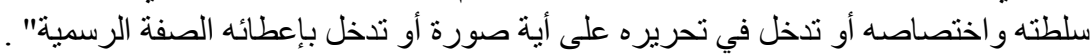

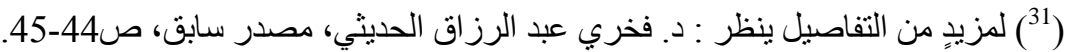

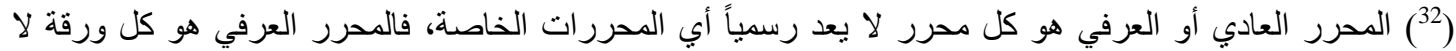

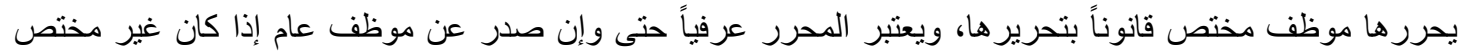

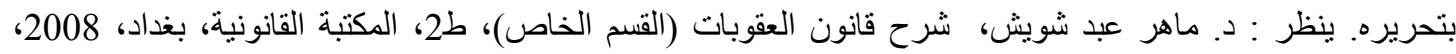

(33) لتفاصيلٍ أكثر حول هذا الثأن ينظر : د. ماهر عبد شويش، مصدر سابق، ص437.

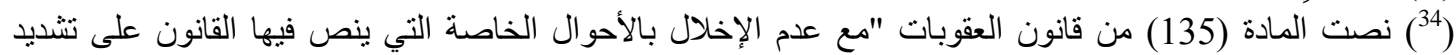

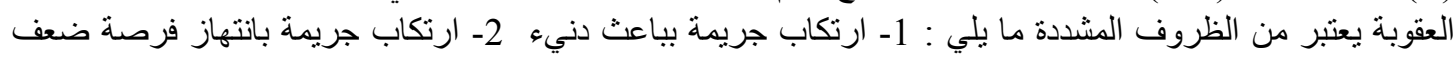

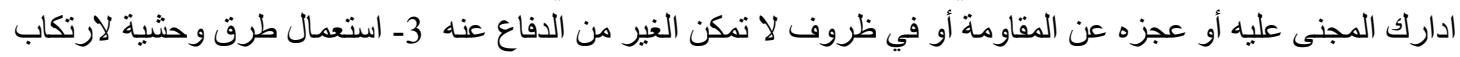

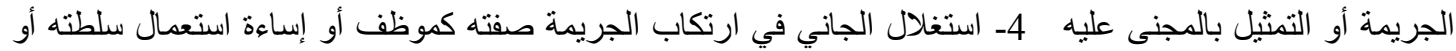

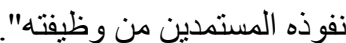

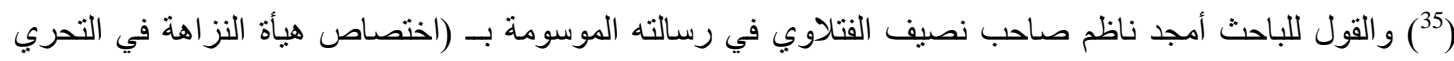

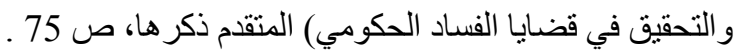



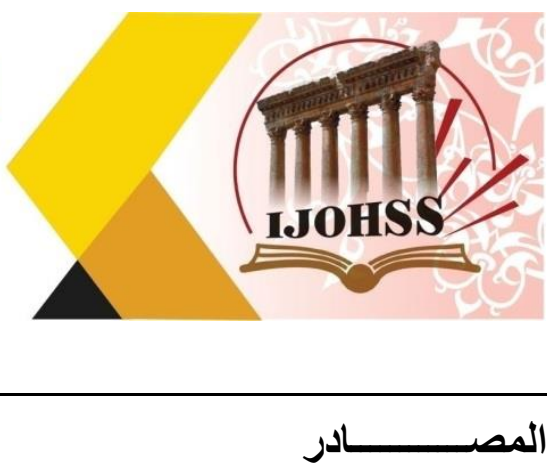

أولاً : الكتب باللغة العربية الئة

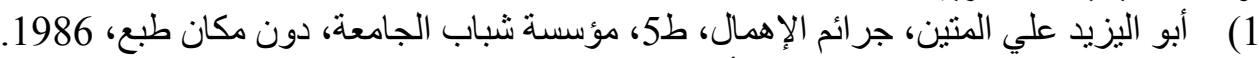

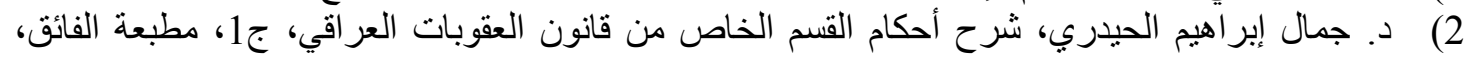

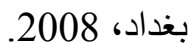

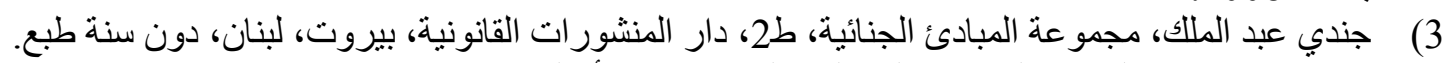

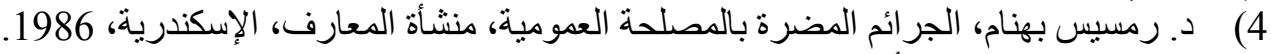

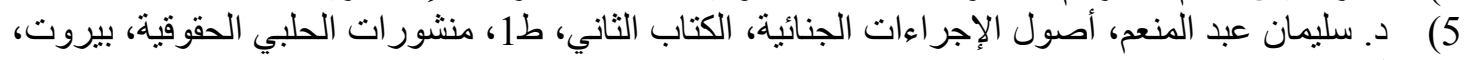
لبنان، 2005.

6) د. عبد الحميد الثواربي، الجنايات والجنح المضرة بالمصلحة العامة في ضوء الفقه والقضاء، منشأة

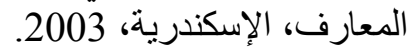

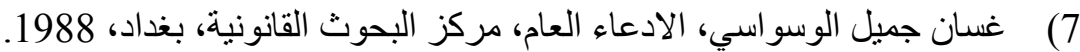

8) د. فخري عبد الرزاق الحديثي، شرح قانون العقوبات (القسم الخاص)، ط2، المكتبة القانونية، بغداد، 2007

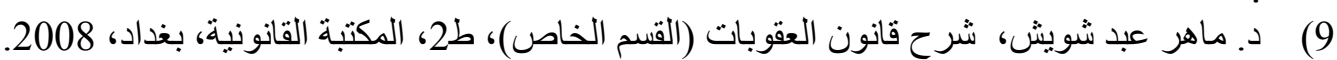

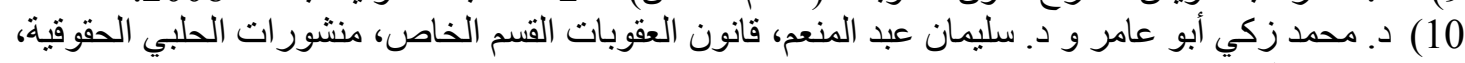

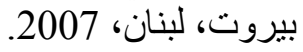

11) د. محمد صبحي نجم، شرح قانون العقوبات (القسم الخاص)، ط1، دار الثقافة للنشر و التوزيع، عمان، .2006

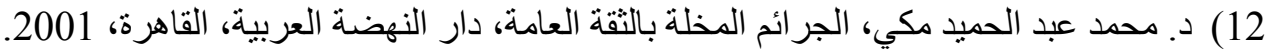

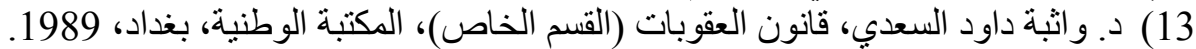

ثانياً : الرسائل الجامعية دالية

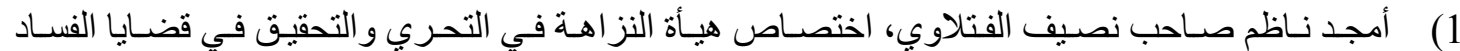

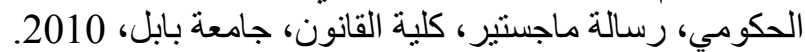

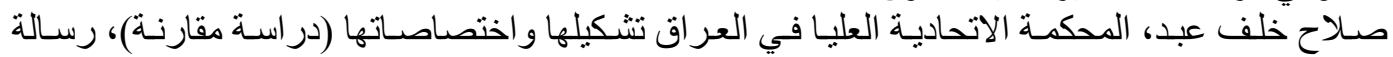
ماجستير، كلية الحقوق، جامعة النهرين، الأندادية 2011.

ثالثاً : البحوث العلمية البية

1) البي إسماعيل هزيم، جريمة استغلال النفوذ، بحث مقدم إلى مجلس القضاء الأعلى، وهو جزء من متطلبات

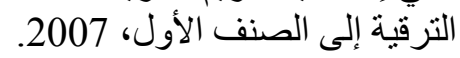

2) علي السباك، جر ائم الفساد الإداري المعاقب المباد عليها في القانون العر اقي، بحث منشور في مجلة دليل الموظف

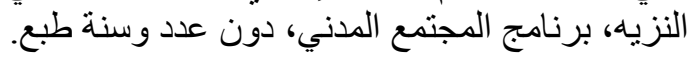

رابعاً : التشريعات برن

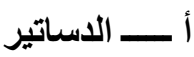

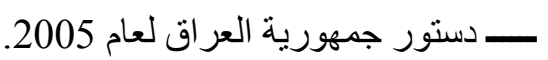

ب بـ القوانين

1. قانون المر افعات المدنية رقم (83) لسنة 1969 المعدل.

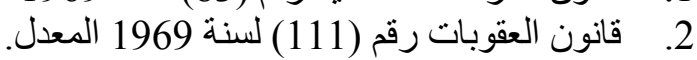

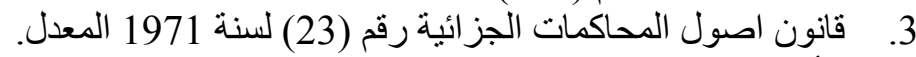

4. الأمر الصادر عن سلطة الائتلاف المؤقتة (المنحلة) رقم (55) لسنة 2004. 


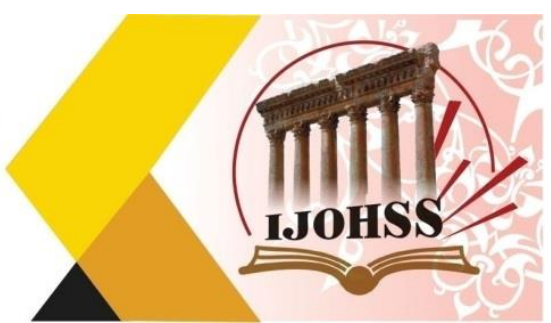

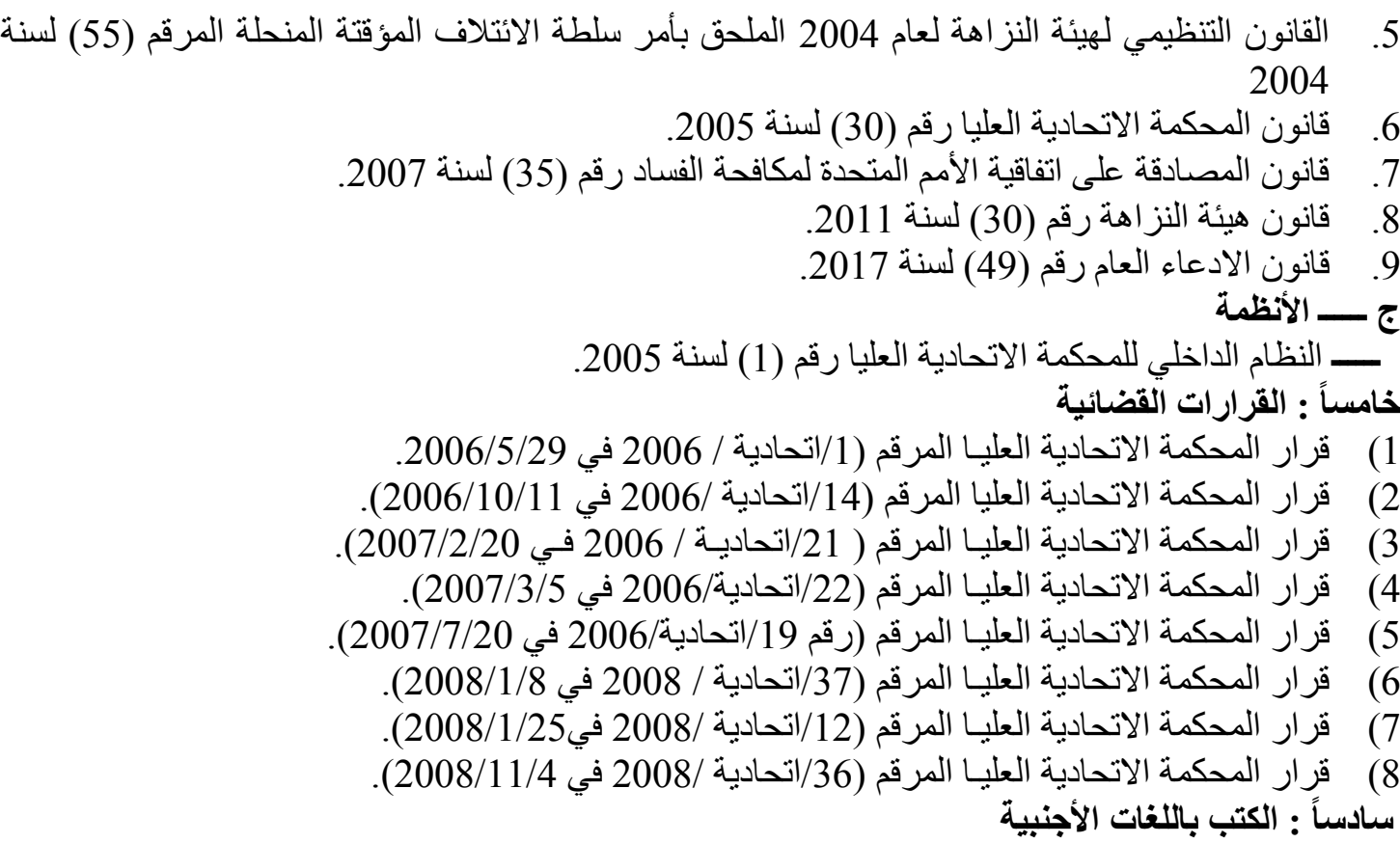

1) Mari - Liss Liiv : The causes administrative corruption, University of Tartu, Faculty of social sciences, Thesis for the master's degree in public administration , 2004.

2) Mohammad Mohabbat Khan, Pollitical and Administrative corruption, Englewood cliffs, Nj, Princeton Hall, inc, 2004.

\section{References}

\section{First: books are in Arabic}

1. Abu Al-Yazid Ali Al-Mateen, Crimes of Negligence, 5th Edition, University Youth Foundation, without a place of printing, 1986.

2. Dr. Jamal Ibrahim Al-Haidari, Explanation of the provisions of the Special Section of the Iraqi Penal Code, Part 1, Al-Faiq Press, Baghdad, 2008.

3. Abd al-Malik Soldier, The Body of Criminal Principles, 2nd Edition, Legal Publications House, Beirut, Lebanon, without a year of printing. 


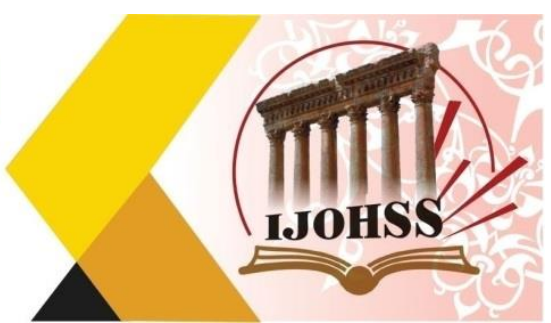

4. Dr. Ramses Behnam, Crimes Harmful to the Public Interest, Knowledge Establishment, Alexandria, 1986.

5. Dr. Suleiman Abdel Moneim, The Fundamentals of Criminal Procedure, Book Two, First Edition, Al-Halabi Legal Publications, Beirut, Lebanon, 2005.

6. Dr. Abdel Hamid Al-Shawarby, Felonies and Misdemeanors Harmful to the Public Interest in the Light of Jurisprudence and the Judiciary, Al-Ma'arif Institute, Alexandria, 2003.

7. Ghassan Jamil Al-Awassi, Public Prosecution, Legal Research Center, Baghdad, 1988.

8. Dr. Fakhri Abd Al-Razzaq Al-Hadithi, Explanation of the Penal Code (Special Section), 2nd Edition, The Legal Library, Baghdad, 2007.

9. Dr. Maher Abd Shwish, Explanation of the Penal Code (Special Section), 2nd Edition, The Legal Library, Baghdad, 2008.

10. Dr. Muhammad Zaki Abu Amer and d. Suleiman Abdel Moneim, Penal Code, Special Section, Al-Halabi Human Rights Publications, Beirut, Lebanon, 2007.

11. Dr. Muhammad Subhi Najm, Explanation of the Penal Code (Special Section), 1st Edition, House of Culture for Publishing and Distribution, Amman, 2006.

12. Dr. Mohamed Abdel-Hamid Makki, Crimes against Public Trust, Dar Al-Nahda Al-Arabiya, Cairo, 2001.

13. Dr. Wathba Dawood Al-Saadi, Penal Code (Special Section), The National Library, Baghdad, 1989.

\section{Second: university theses}

1. Amjad Nazem Sahib Nassif Al-Fatlawi, The Integrity Commission specialization in investigating and investigating cases of government corruption, Master Thesis, College of Law, University of Babylon, 2010.

2. Salah Khalaf Abd, the Federal Supreme Court in Iraq, its formation and terms of reference (a comparative study), Master Thesis, Faculty of Law, Nahrain University, 2011.

\section{Third: scientific research}

1. Haqqi Ismail Hazeem, The Crime of Exploitation of Influence, a study submitted to the Supreme Judicial Council, which is part of the requirements for promotion to the first class, 2007.

2. Ali Al-Sabbak, Administrative Corruption Crimes Punished in Iraqi Law, a research published in the Journal of the Honest Employee's Handbook, Civil Society Program, without number and year of publication. 


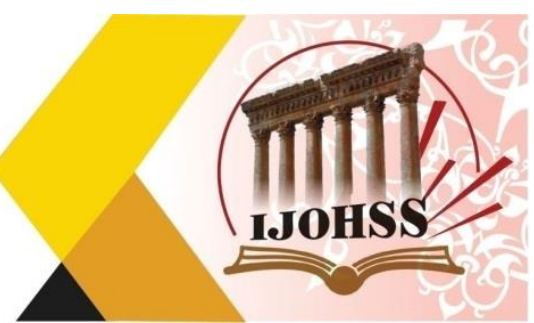

\section{Fourth: Legislation}

\section{A- Constitutions}

The Constitution of the Republic of Iraq for the year 2005.

\section{B- Laws}

1. Civil Procedure Law No. (83) of 1969, as amended.

2. Penal Code No. (111) of 1969 , as amended.

3. Code of Criminal Procedure No. 23 of 1971, as amended.

4. Order issued by the Coalition Provisional Authority (dissolved) No. (55) of 2004.

5. The Integrity Commission Organizational Law for the year 2004 attached to the dissolved Coalition Provisional Authority Order No. 55 of 2004.

6. Law of the Federal Supreme Court No. (30) of 2005.

7. Law No. (35) of 2007 Ratifying the United Nations Convention against Corruption.

8. The Integrity Commission Law No. (30) of 2011.

9. Public Prosecution Law No. (49) of 2017.

\section{C-Systems}

The rules of procedure of the Federal Supreme Court No. (1) of 2005.

\section{Fifth: Judicial decisions}

1. Supreme Federal Court Decision No. (1 / Federal / 2006) of 05/29/2006).

2. Federal Supreme Court Decision No. (14 / Federal / 2006 on 10/11/2006).

3. Federal Supreme Court Decision No. (21 / Federal / 2006 on 02/20/2007).

4. Supreme Federal Court Decision No. (22 / Federal / 2006 on 3/5/2007).

5. Supreme Federal Court Decision No. (No. 19 / Federal / 2006 on 7/20/2007).

6. Supreme Federal Court Decision No. (37 / Federal / 2008 in 1/8/2008).

7. Supreme Federal Court Decision No. (12 / Federal / 2008 on 1/25/2008).

8. Supreme Federal Court Decision No. (36 / Federal / 2008 on 4/11/2008).

\section{Sixth: Books in foreign languages}

1) Mari - Liss Liiv : The causes administrative corruption, University of Tartu, Faculty of social sciences, Thesis for the master's degree in public administration , 2004.

2) Mohammad Mohabbat Khan, Pollitical and Administrative corruption, Englewood cliffs, Nj, Princeton Hall, inc, 2004. 